\title{
Lycopus lucidus Turcz ameliorates DNCB-induced atopic dermatitis in BALB/c mice
}

\author{
GA-YUL MIN ${ }^{1}$, EUN-YOUNG KIM ${ }^{1}$, SOOYEON HONG ${ }^{1}$, JAE-HYUN KIM ${ }^{1}$, MINSUN KIM ${ }^{1}$, \\ EOM JI KIM ${ }^{1}$, JAE HO PARK ${ }^{2}$, YOUNGJOO SOHN ${ }^{1}$ and HYUK-SANG JUNG ${ }^{1}$ \\ ${ }^{1}$ Department of Anatomy, College of Korean Medicine, Kyung Hee University, Seoul 02447; \\ ${ }^{2}$ Department of Pharmaceutical Science, Jungwon University, Goesan, Chungbuk 28024, Republic of Korea
}

Received April 24, 2021; Accepted July 28, 2021

DOI: $10.3892 / \mathrm{mmr} .2021 .12467$

\begin{abstract}
Atopic dermatitis (AD) is a chronic inflammatory allergic skin disease, characterized by pruritic and eczematous skin lesions. Lycopus lucidus Turcz (LLT) is a perennial herb that has been reported to have various biological properties, including effects on blood circulation, as well as anti-inflammatory, antioxidant, anti-vascular inflammation and wound-healing effects. However, whether LLT improves dermatitis and the underlying mechanisms has yet to be determined. The aim of the present study was to determine whether LLT can improve 2,4-dinitrochlorobenzene (DNCB)-induced dermatitis and to verify the inhibitory effect of LLT on the expression of chemokines and pro-inflammatory cytokines in the $\mathrm{HaCaT}$ immortalized keratinocyte cell line. In addition, the anti-inflammatory function of LLT in RAW264.7 mouse macrophages was investigated. In the DNCB-induced AD mouse model, LLT inhibited infiltration by mast cells, eosinophils and $\mathrm{CD}^{+}$cells in the dorsal skin tissue of AD mice, and suppressed the expression of IgE and IL-6 in serum. In addition, LLT inhibited the phosphorylation of ERK and JNK, as well as $\mathrm{NF}-\kappa \mathrm{B}$ in skin tissue. In the HaCaT cell model induced by TNF- $\alpha /$ IFN- $\gamma$, LLT inhibited the expression of thymus and activation-regulated chemokine, granulocyte-macrophage colony-stimulating factor, monocyte chemoattractant protein-1, TNF- $\alpha$ and IL-1 $\beta$, whilst inhibiting the phosphorylation of $\mathrm{NF}-\kappa \mathrm{B}$. In addition, in the lipopolysaccharide-induced RAW 264.7 cell inflammation model, LLT inhibited the expression of TNF- $\alpha$ and IFN- $\gamma$, the nuclear translocation of NF- $\kappa$ B and the phosphorylation of ERK and JNK. These results suggested
\end{abstract}

Correspondence to: Professor Hyuk-Sang Jung, Department of Anatomy, College of Korean Medicine, Kyung Hee University, 753-ho, SPACE 21, 26-6 Kyungheedae, Dongdaemun, Seoul 02447, Republic of Korea

E-mail: jhs@khu.ac.kr

Key words: atopic dermatitis, Lycopus lucidus Turcz, 2,4-dinitrochlorobenzene, HaCaT, MAPK, NF-кB, thymus and activation-regulated chemokine that LLT may be a promising candidate for the treatment of inflammatory dermatitis.

\section{Introduction}

Atopic dermatitis (AD) is a common chronic inflammatory skin disease (1). AD generally presents in infancy and early childhood, and its prevalence is increasing worldwide (2). Environmental, pharmacological and genetic factors may play a role in AD by disturbing the balance of the immune system (3). The main symptoms of AD include erythema, itching, eczematous lesions, excoriation, edema and thickening of the skin $(4,5)$. In severe cases, fluid extravasation and bacterial infections may develop (5). Steroids, antihistamines and immunosuppressive agents are currently used to treat AD (6,7). However, these agents are associated with a variety of adverse effects when used in the long term or at high doses (6-8). Therefore, new, effective alternative medicines are needed for $\operatorname{AD}(7,8)$.

AD symptoms, such as skin thickening and cracking, are caused by T helper 1 (Th1) and T helper 2 (Th2) cells (9). The production of cytokines by $\mathrm{Th} 2$ cells increases the production of $\mathrm{IgE}$, as well as the infiltration of eosinophils and mast cells into inflamed skin tissue (10-12). IgE is a major mediator of mast cell activation and contributes to the release of inflammatory mediators, including histamine and cytokines (13). The MAPK signaling cascade plays a key role in the differentiation of inflammatory cells (14). The transcription factor $\mathrm{NF}-\kappa \mathrm{B}$ also plays a major role in regulating several inflammatory mediators (15).

AD is induced by various chemokines and inflammatory cytokines. Thymus and activation-regulated chemokine [TARC/C-X-C motif chemokine ligand 17 (CXCL17)] is produced by dendritic cells, endothelial cells, keratinocytes and fibroblasts, and induces Th2 cell migration to the inflammatory site, as these cells express the receptor for TARC/CCL17. Therefore, TARC is an important chemokine in inflammatory skin diseases (16) and is used as a clinical biomarker to measure atopic diseases (16). Granulocyte-macrophage colony-stimulating factor (GM-CSF) is also involved in the initiation and maintenance of chronic inflammation by activating Langerhans cells (17), as well as by causing hyperproliferation (18) and apoptosis of keratinocytes (19). 
In addition, high levels of GM-CSF were observed in the skin of patients with AD (20). Monocyte chemoattractant protein-1 (MCP-1) plays a key role in mast cell degranulation, histamine release from basophils and transformation of undifferentiated $\mathrm{T}$ cells to Th2 cells (21). In addition, scratching of itchy skin causes secretion of various pro-inflammatory cytokines, including IL-1 $\beta$, TNF- $\alpha$ and IL-4, from keratinocytes, thereby aggravating the inflammatory reaction $(11,22)$. According to previous reports, it is known that the expression of TNF- $\alpha / \mathrm{IFN}-\gamma$-induced adhesion proteins and pro-inflammatory cytokines/chemokines in keratinocytes is suppressed by inhibiting the activity of MAPKs and NF- $\mathrm{B}(23,24)$.

Lycopus lucidus Turcz (LLT) is a perennial herb known as 'Taekran' in Korea (25). Traditionally, LLT has been used to treat amenorrhea, dysmenorrhea, edema, carbuncles and sores (26). Recently, LLT has been reported to have various biological properties, including effects on the blood circulation (25), anti-inflammatory (27), antioxidant (28), anti-vascular inflammation and wound-healing effects $(27,29)$, suggesting that LLT may also affect the mechanism underlying AD.

In the present study, the thickness of the epidermis and dermis and the infiltration by mast cells and eosinophils were evaluated in mice with 2,4-dinitrochlorobenzene (DNCB)-induced AD. In addition, the expression levels of serum IgE and IL- 6 and members of the NF- $\kappa$ B and MAPK signaling pathways were investigated. To examine the mechanism of AD inhibition, the expression of chemokines and pro-inflammatory cytokines and NF- $\mathrm{B} / \mathrm{MAPK}$ signaling pathway molecules was examined in TNF- $\alpha / \mathrm{IFN}-\gamma$-stimulated HaCaT cells. Furthermore, the expression of Th1 cytokines (IFN- $\gamma$ and $\mathrm{TNF}-\alpha$ ) and $\mathrm{NF}-\kappa \mathrm{B} / \mathrm{MAPK}$ signaling pathway-related proteins was examined in lipopolysaccharide (LPS)-stimulated RAW 264.7 cells. The results of these experiments were integrated to determine the potential applicability of LCL in the treatment of AD.

\section{Materials and methods}

Reagents. DNCB, toluidine blue, hematoxylin, eosin, human TNF- $\alpha$, human IFN- $\gamma$, LPS, caffeic acid, protease inhibitor cocktail and phosphatase inhibitor cocktail were purchased from Sigma-Aldrich (Merck KGaA). Mouse IgE (cat. no. 555248), mouse IL-6 (cat. no. 555240), human GM-CSF (cat. no. 555126), human TNF- $\alpha$ (cat. no. 555212), human IL-1 $\beta$ (cat. no. 557953), human MCP-1 (cat. no. 555179), human IL-6 (cat. no. 555220) and human IL-8 (cat. no. 555244) ELISA kits were purchased from BD Biosciences. Polink-2 Plus AP rabbit kit (cat. no. D70-18) was purchased from GBI Labs. Antibodies against CD4 (cat. no. ab183685; type, monoclonal; species, anti-mouse) and CD8 (cat. no. ab209775; type, monoclonal; species, anti-mouse) were obtained from Abcam. Antibodies against phosphorylated (p)-ERK (cat. no. cs-4370; type, monoclonal, species, anti-rabbit), total (t)-ERK (cat. no. cs-4695; type, monoclonal; species, anti-rabbit), p-JNK (cat. no. cs-4668; type, monoclonal; species, anti-rabbit), t-JNK (cat. no. cs-9258; type, monoclonal; species, anti-rabbit), NF- $\mathrm{B}$ (cat. no. cs-8242; type, monoclonal; species, anti-rabbit), p-NF-кB (cat. no. cs-3033; type, monoclonal; species, anti-rabbit) and IkB (cat. no. cs-4814S; type, monoclonal; species, anti-rabbit) were purchased from
Cell Signaling Technology, Inc. Anti-lamin B antibody (cat. no. sc-6216; type, polyclonal; species, anti-mouse) and anti-actin antibody (cat. no. sc-8432; type, polyclonal; species, anti-mouse) were purchased from Santa Cruz Biotechnology, Inc. A SuperScript ${ }^{\mathrm{TM}}$ IV reverse transcriptase was purchased from Invitrogen (Thermo Fisher Scientific, Inc.). Taq polymerase was obtained from Kapa Biosystems (Roche Diagnostics). PCR primers were purchased from GenoTech Corp. DMEM was purchased from Welgene, Inc. Goat serum (16210064 for IHC), FBS, penicillin/streptomycin (P/S) and Dulbecco's PBS (DPBS) were purchased from Gibco (Thermo Fisher Scientific, Inc.). An aqueous non-radioactive cell proliferation assay (MTS) was purchased from Promega Corporation.

Preparation of LLT. LLT was purchased from Kyung Hee University Healthcare System (Seoul, Korea). LLT extract was prepared by decocting $500 \mathrm{~g}$ of the dried herb with 51 boiling distilled water for $2 \mathrm{~h}$, then filtering the mixture using filter paper. The extract was concentrated in a rotary evaporator and lyophilized. The powder (57.1 g; yield ratio, $11.4 \%)$ was stored at $-20^{\circ} \mathrm{C}$ until use.

Animals and induction of AD-like lesions and drug treatment in mice. All animal experiments were performed with the approval of the Institutional Animal Care and Use Committee of Kyung Hee University Institutional Animal Care and Use Committee [KHUASP (SE)-15-116]. A total of 32 male 6-week-old BALB/c mice (weighing 18-20 g) were obtained from Nara Biotech. Animal experiments were performed in an air-conditioned room, with a temperature of $23 \pm 2^{\circ} \mathrm{C}$, and food and water were provided ad libitum. After an acclimatization period of 7 days, the mice were divided into four groups ( $n=8$ per group;) as follows: Normal (vehicle-treated), Control (DNCB-sensitized), LLT low (LLT-L; DNCB + $1 \mathrm{mg} / \mathrm{kg}$ LLT) and LLT high (LLT-H; DNCB $+5 \mathrm{mg} / \mathrm{kg}$ LLT). The mice were anesthetized with isoflurane diluted in $100 \%$ oxygen $(4 \%$ induction and $2 \%$ maintenance). The dorsal skin of the mice was shaved with a clipper 1 day before the experiment. In the first sensitization, the mice (control, LLT-L and LLT-H groups) were treated with $200 \mu 10.5 \%$ DNCB solution (dissolved in a 3:1 mixture of acetone and olive oil) for 3 days. The normal group was treated with PBS applied to the backs of the mice during the first sensitization period. In the second sensitization, $200 \mu 11 \%$ DNCB solution was applied to the dorsal skin of the control, LLT-L and LLT-H groups (once every 3 days, 6 times in total). The normal group was treated with $200 \mu 1$ 9:1 mixture of PBS and olive oil to the dorsal skin. The LLT-treated groups were challenged with $200 \mu 1$ LLT in a 9:1 mixture of PBS and olive oil (LLT-L, DNCB + $1 \mathrm{mg} / \mathrm{kg}$ LLT; and LLT-H, DNCB $+5 \mathrm{mg} / \mathrm{kg}$ LLT) $2 \mathrm{~h}$ after the application of DNCB daily. The normal and control groups were treated with a $200 \mu 1$ 9:1 mixture of PBS and olive oil (Fig. 1A). The health and behavior of the mice were monitored daily and no animals died during the experiment. The following humane endpoints were used: i) Walking uncomfortably and difficulty consuming feed or water; ii) difficulty maintaining a normal posture due to weakness; iii) decrease in weight of $>20 \%$ compared with the control group of the same age; iv) coarse breathing, cyanosis, chronic discomfort or constipation; v) hematological 
A

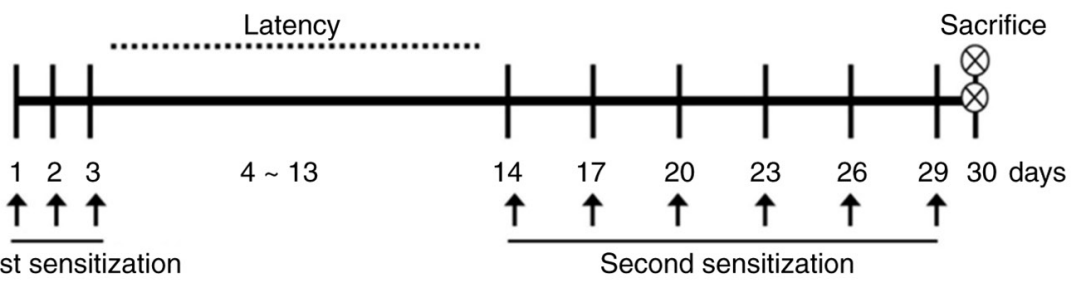

$0.5 \%$ DNCB $200 \mu \mathrm{l}$

in acetone/olive oil (3:1)

$1 \%$ DNCB $200 \mu \mathrm{l}$

in PBS/olive oil (9:1)

Topical application with sample

at $2 \mathrm{~h}$ after DNCB application every day

B

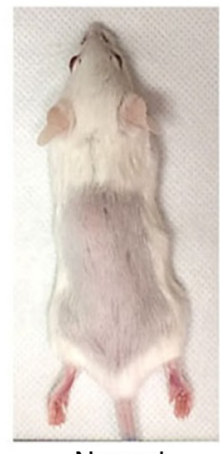

Normal

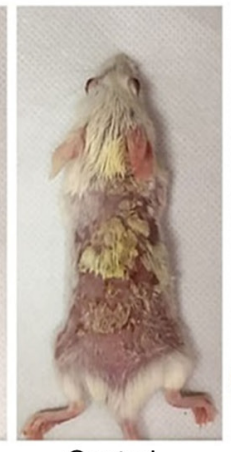

Control

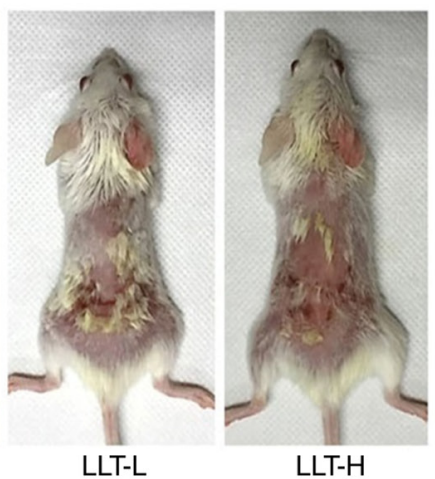

LLT-L
C

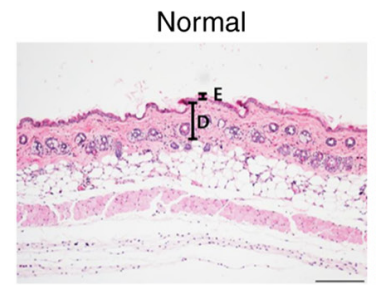

LLT-L

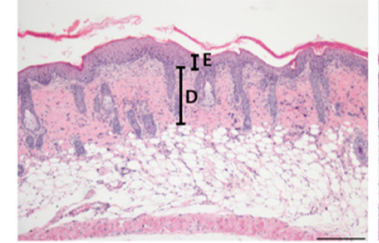

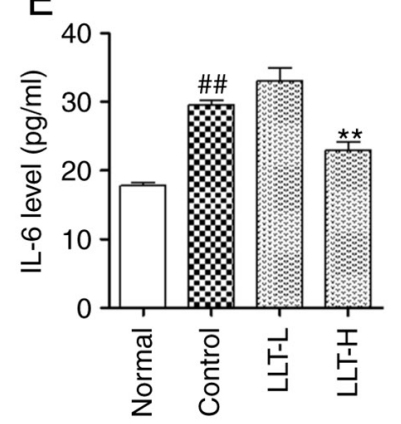

E
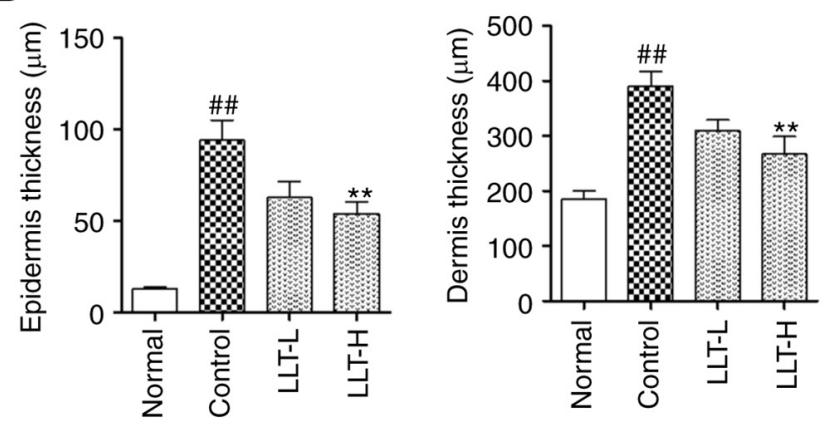

Control



LLT-H
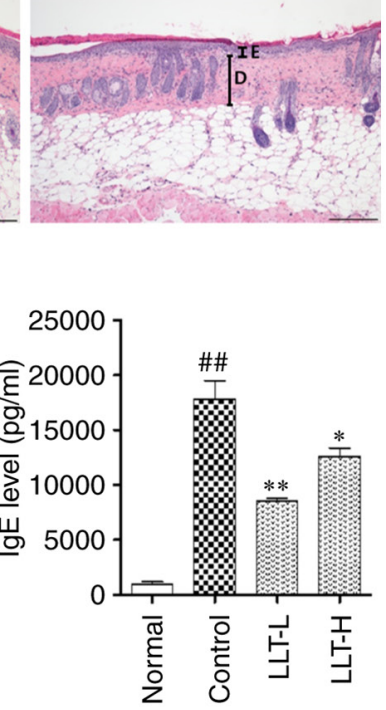

Figure 1. Effects of LLT on the histological characteristics of mice with DNCB-induced AD. (A) Schematic diagram of the experimental schedule. (B) Clinical characteristics of each treatment group on day 30. (C) Epidermal and dermal thickness was examined by H\&E staining of skin sections. Magnification, x100. Scale bar, $200 \mu \mathrm{m}$. (D) Measurement of epidermal and dermal thickness. (E) Serum IgE and IL-6 levels were quantified by ELISA. Data represent the mean \pm SEM. $n=8 .{ }^{\# / /} \mathrm{P}<0.01$ vs. normal group; ${ }^{*} \mathrm{P}<0.05$ and ${ }^{* *} \mathrm{P}<0.01$ vs. control group. Normal group, vehicle-treated; control group, DNCB-sensitized; LLT-L group, DNCB $+1 \mathrm{mg} / \mathrm{kg}$ LLT; LLT-H group, DNCB $+5 \mathrm{mg} / \mathrm{kg}$ LLT. AD, atopic dermatitis; LLT, Lycopus lucidus Turcz; DNCB, 2,4-dinitrochlorobenzene; E, epidermis; D, dermis.

or blood biochemistry parameters indicating organ function decline that compromises survival ability; vi) falling into an unconscious state and not responding to external stimuli. After the experiment was completed, the mice were deeply anesthetized intraperitoneally with $80 \mathrm{mg} / \mathrm{kg}$ pentobarbital sodium, and 800-1,000 $\mu \mathrm{l}$ blood was collected by cardiac puncture. After death was confirmed by cessation of breathing and blood circulation, a dorsal skin sample was collected.

Histological analysis. The dorsal skin was fixed in $10 \%$ neutral buffered formalin (NBF) at room temperature for 1 day, and the tissues were washed with tap water for 1 day. The tissues were embedded in paraffin and cut into $5-\mu \mathrm{m}$ sections using a rotary microtome (Zeiss AG). The tissues were deparaffinized for $3 \mathrm{~min}$, rehydrated for $3 \mathrm{~min}$, and stained with hematoxylin and eosin (H\&E) for $3 \mathrm{~min}$ or toluidine blue for $3 \mathrm{~min}$. All staining reactions were performed at room temperature. The infiltration by eosinophils was examined under a light microscope (magnification, $x 400 ; 10$ fields per section). The infiltration of mast cells was observed (magnification, x200; 3 fields per section). In addition, the thickness of the dermis and epidermis were also analyzed (magnification, x100; 3 fields per section). The skin thickness and inflammatory cell count were measured using ImageJ software (version 1.46; National Institutes of Health).

Immunohistochemistry (IHC) staining. The dorsal skin was fixed in $10 \% \mathrm{NBF}$ at room temperature for 1 day, and the 
tissues were washed with tap water for 1 day. The tissues were embedded in paraffin and cut into 5- $\mu \mathrm{m}$ sections using a rotary microtome (Zeiss AG). The tissues were deparaffinized and rehydrated. For epitope retrieval, the tissue was placed in sodium citrate buffer ( $0.1 \mathrm{M}$ citric acid; $0.1 \mathrm{M}$ sodium citrate) and heated using an Electric Pressure Cooker (CPC-600; Cuisinart). After the endogenous peroxidase activity was blocked using $0.3 \%(\mathrm{v} / \mathrm{v}) \mathrm{H}_{2} \mathrm{O}_{2}$ in methanol at room temperature for $30 \mathrm{~min}, 10 \%$ goat serum (Gibco; Thermo Fisher Scientific, Inc.) in PBS was used for blocking at room temperature for $10 \mathrm{~min}$. Subsequently, the tissues were incubated with primary antibodies (dilution 1:100) at $4^{\circ} \mathrm{C}$ for overnight. The tissue was incubated for $1 \mathrm{~h}$ at room temperature with a biotinylated secondary antibody (dilution 1:100). Finally, the tissues were stained with Polink-2 Plus AP rabbit kit for $30 \mathrm{~min}$ at room temperature, and the nuclei were counterstained with Harris hematoxylin for $5 \mathrm{~min}$ at room temperature. The stained tissue was observed under a light microscope (BX51; Olympus Corporation) at a magnification of $\mathrm{x} 400$ (10 fields per section). The $\mathrm{CD}^{+}$and $\mathrm{CD} 8^{+}$cells were counted using ImageJ software (version 1.51j8; National Institutes of Health).

Cell culture. HaCaT cells were purchased from the CLS Cell Lines Service GmbH (cat. no. CLS 300493). HaCaT cells were cultured in DMEM with $10 \%$ FBS and 1\% P/S. RAW 264.7 cells were obtained from the Korean Cell Line Bank (Korean Cell Line Research Foundation; cat. no. KCLB 40071). RAW 264.7 cells were cultured in DMEM with $10 \%$ FBS and $1 \% \mathrm{P} / \mathrm{S}$. Both cell lines were cultured in a cell incubator at $37^{\circ} \mathrm{C}$ in a humidified atmosphere of $5 \% \mathrm{CO}_{2}$ in air.

Ex vivo ELISA. To prepare serum, blood collected from the mice was separated by centrifugation at $14,310 \times \mathrm{g}$ and $4^{\circ} \mathrm{C}$ for $10 \mathrm{~min}$. The concentrations of IgE and IL-6 in the serum were detected using ELISA kits in vitro. The HaCaT cells were seeded in a 6 -well plate at a density of $1 \times 10^{6}$ cells/well. After $24 \mathrm{~h}$, the cells were pretreated with LLT at concentrations of 1,10 and $100 \mu \mathrm{g} / \mathrm{ml}$ for $1 \mathrm{~h}$ and stimulated with TNF- $\alpha / \mathrm{IFN}-\gamma$ $(10 \mathrm{ng} / \mathrm{ml})$ for $24 \mathrm{~h}$ in a $\mathrm{CO}_{2}$ incubator maintained at $37^{\circ} \mathrm{C}$. The culture medium was not changed for pretreatment and stimulant treatment. The concentrations of various pro-inflammatory cytokines and chemokines (GM-CSF, TNF- $\alpha$, IL-1 $\beta$, MCP-1, IL-6 and IL-8) in the culture medium were also detected using ELISA kits. All experiments were carried out according to the manufacturer's protocol.

\section{Western blot analysis}

Ex vivo. To extract nuclear fraction, the frozen skin tissue was homogenized with NE-PER nuclear and cytoplasmic extraction reagent (cat. no. 78835, Thermo Fisher Scientific Inc.). To extract whole protein, the frozen skin tissue was homogenized with lysis buffer (20 mM HEPES, pH 7.5; $1.5 \mathrm{mM} \mathrm{MgCl}_{2}$; $0.2 \mathrm{mM}$ EDTA; $0.1 \mathrm{M} \mathrm{NaCl}$; $0.2 \mathrm{mM}$ DTT; $0.5 \mathrm{mM} \mathrm{Na}_{3} \mathrm{VO}_{4}$ ). Proteins were obtained after centrifugation at 58,440 $\mathrm{x} g$ for $30 \mathrm{~min}$ at $4^{\circ} \mathrm{C}$. In vitro. $\mathrm{HaCaT}$ cells were seeded in a 6-well plate, with a density of $1 \times 10^{6}$ cells/well. After $24 \mathrm{~h}$, the cells were pretreated with LLT at concentrations of 1,10 and $100 \mu \mathrm{g} / \mathrm{ml}$ for $1 \mathrm{~h}$ and stimulated with TNF- $\alpha / \mathrm{IFN}-\gamma(10 \mathrm{ng} / \mathrm{ml})$ for $5 \mathrm{~min}$ (nuclear and cytoplasmic protein) and $30 \mathrm{~min}$ (whole protein) in a $\mathrm{CO}_{2}$ incubator maintained at $37^{\circ} \mathrm{C}$. The culture medium was not changed for pretreatment and stimulant treatment. RAW 264.7 cells were seeded in a 6-well plate, with a density of $1 \times 10^{6}$ cells/well. After $24 \mathrm{~h}$, the cells were pretreated with LLT at concentrations of 1,10 and $100 \mu \mathrm{g} / \mathrm{ml}$ for $1 \mathrm{~h}$ and stimulated with LPS $(1 \mu \mathrm{g} / \mathrm{ml})$ for $5 \mathrm{~min}$ (nuclear and cytoplasmic protein) and $30 \mathrm{~min}$ (total protein) in a $\mathrm{CO}_{2}$ incubator maintained at $37^{\circ} \mathrm{C}$. The culture medium was not changed for pretreatment and stimulant treatment. When extracting the nuclear and cytoplasmic protein, the HaCaT and RAW 264.7 cells were washed with PBS and lysed with nuclear and cytoplasmic extraction reagents. To extract the whole protein, the cells were washed with DPBS and proteins were extracted using RIPA buffer (50 mM Tris-Cl, $150 \mathrm{nM} \mathrm{NaCl}, 1 \% \mathrm{NP}-40$, $0.5 \%$ sodium deoxycholate, $0.1 \%$ SDS, protease inhibitor cocktail and phosphatase inhibitor cocktail) for total protein lysis.

The same method was used for ex vivo and in vitro experiments after protein extraction. The protein concentration was determined using a BCA assay. The protein samples $(30 \mu \mathrm{g})$ were separated by SDS-PAGE on $10 \%$ gels, then transferred to a nitrocellulose membrane. The membrane was blocked with $5 \%$ skimmed milk for $1 \mathrm{~h}$ at room temperature. After blocking, the membrane was incubated overnight with primary antibodies against t-ERK (dilution 1:1,000), p-ERK (dilution 1:1,000), t-JNK (dilution 1:1,000), p-JNK (dilution 1:1,000), t-p38 (dilution 1:1,000), p-p38 (dilution 1:1,000), NF- $\kappa \mathrm{B}$ (dilution 1:1,000), $\mathrm{p}-\mathrm{NF}-\kappa \mathrm{B}$ (dilution 1:1,000), lamin $\mathrm{B}$ (dilution 1:1,000), I $\mathrm{B}$ (dilution 1:1,000) and actin (dilution 1:1,000) at $4^{\circ} \mathrm{C}$. The membrane was then incubated with secondary antibodies (dilution 1:10,000) for $1 \mathrm{~h}$ at room temperature. The protein bands were visualized using an enhanced chemiluminescence (cat. no. RPN2106; Cytiva) detection reagent and semi-quantified using ImageJ software (version 1.51j8, National Institutes of Health).

Cell viability assay. The MTS assay was used to evaluate the cytotoxicity of LLT in HaCaT and RAW 264.7 cells. The cells were seeded in a 96 -well plate at a density of $5 \times 10^{4}$ cells/well. After $24 \mathrm{~h}$, LLT $(1,10$ or $100 \mu \mathrm{g} / \mathrm{ml})$ was added to the medium for $24 \mathrm{~h}$ in a $\mathrm{CO}_{2}$ incubator maintained at $37^{\circ} \mathrm{C}$. In addition, in order to confirm the toxicity of LLT in HaCaT cells stimulated with TNF- $\alpha / \mathrm{IFN}-\gamma$, the cells were seeded in a 96-well plate at a density of $5 \times 10^{4}$ cells/well. After $24 \mathrm{~h}$, LLT (1, 10 or $100 \mu \mathrm{g} / \mathrm{ml})$ and TNF- $\alpha / \mathrm{IFN}-\gamma(10 \mathrm{ng} / \mathrm{ml})$ was added to the medium for $24 \mathrm{~h}$ in a $\mathrm{CO}_{2}$ incubator maintained at $37^{\circ} \mathrm{C}$. After each reaction was completed, a volume of $20 \mu \mathrm{l}$ MTS solution was then added to each well for $2 \mathrm{~h}$, and then the optical density was measured using a microplate reader at a wavelength of $562 \mathrm{~nm}$.

Reverse transcription PCR (RT-PCR) analysis. HaCaT cells were seeded in a 6 -well plate at a density of $1 \times 10^{6}$ cells/well. After $24 \mathrm{~h}$, the cells were pretreated with LLT at concentrations of 1,10 and $100 \mu \mathrm{g} / \mathrm{ml}$ for $1 \mathrm{~h}$ at $37^{\circ} \mathrm{C} \mathrm{CO}_{2}$ incubator and stimulated with TNF- $\alpha / \mathrm{IFN}-\gamma(10 \mathrm{ng} / \mathrm{ml})$ for $24 \mathrm{~h}$ in a $\mathrm{CO}_{2}$ incubator maintained at $37^{\circ} \mathrm{C}$. The culture medium was not changed prior to pretreatment and stimulation. RAW 264.7 cells were seeded in a 6 -well plate at a density of $2 \times 10^{6}$ cells/well. After $24 \mathrm{~h}$, the cells were co-treated with LLT at concentrations of 1,10 and $100 \mu \mathrm{g} / \mathrm{ml}$ and LPS $(1 \mu \mathrm{g} / \mathrm{ml})$ for $6 \mathrm{~h}$ in a $\mathrm{CO}_{2}$ incubator maintained at $37^{\circ} \mathrm{C}$. 
Table I. Primer sets for reverse transcription PCR.

\begin{tabular}{|c|c|c|c|c|c|}
\hline Primer name & Primer sequence, $5^{\prime} \rightarrow 3^{\prime}$ & $\begin{array}{l}\text { Gene } \\
\text { name }\end{array}$ & $\begin{array}{l}\text { Number } \\
\text { of cycles }\end{array}$ & $\begin{array}{c}\text { Annealing } \\
\text { temperature, }{ }^{\circ} \mathrm{C}\end{array}$ & Genbank accession no. \\
\hline h-TARC F & ACTGCTCCAGGGATGCCATCGTTTTT & CCL17 & 44 & 57.5 & NM_002987.3 \\
\hline h-TARC R & ACAAGGGGATGGGATCTCCCTCACTG & & & & \\
\hline h-GAPDH F & CGTCTAGAAAAACCTGCCAA & $G A P D H$ & 30 & 50 & NM_001256799.3 \\
\hline h-GAPDH R & TGAAGTCAAAGGAGACCACC & & & & \\
\hline $\mathrm{m}-\mathrm{TNF}-\alpha \mathrm{F}$ & GCAGAAGAGGCACTCCCCCA & $\operatorname{Tnf}$ & 30 & 58 & NM_001278601.1 \\
\hline m-TNF- $\alpha$ R & GATCCATGCCGTTGGCCAGG & & & & \\
\hline $\mathrm{m}-\mathrm{IFN}-\gamma \mathrm{F}$ & CTCAAGTGGCATAGATGT & Ifng & 38 & 57 & NM_008337.4 \\
\hline m-IFN- $\gamma$ R & GAGATAATCTGGCTCTGCAGGATT & & & & \\
\hline m-GAPDH F & AACTTTGGCATTGTGGAAGG & $G A P D H$ & 30 & 58 & NM_008084.3 \\
\hline m-GAPDH R & ACACATTGGGGGTAGGAACA & & & & \\
\hline
\end{tabular}

h-, human; m-, mouse; TARC, thymus and activation-regulated chemokine; CCL17, C-C motif chemokine ligand 17; F, forward; R, reverse.

Total RNA was extracted using RNAiso Plus (cat. no. 9108; Takara Bio, Inc.), according to the manufacturer's protocol, and the mass of RNA $(2 \mu \mathrm{g})$ was equalized after measuring the concentration of the samples with a NanoDrop (Thermo Fisher Scientific, Inc.) at 250-260 nm. cDNA was prepared from total RNA using a reverse transcription kit, then amplified using a Taq polymerase and target primers. The PCR thermocycling conditions were: $30-44$ cycles of $1 \mathrm{~min}$ at $94^{\circ} \mathrm{C}$ (denaturation), $1 \mathrm{~min}$ at $50-58^{\circ} \mathrm{C}$ (annealing) and $1 \mathrm{~min}$ at $72^{\circ} \mathrm{C}$ (extension)]. The sequences of the primers and specific annealing temperatures are listed in Table I. The amplified samples were separated on a $1.2 \%$ agarose gel, stained with SYBR green (Invitrogen; Thermo Fisher Scientific, Inc.). The stained agarose gel was captured using N $\alpha$ BI (NeoScience). Semi-quantification of the bands was performed using ImageJ software (version 1.51j8; National Institutes of Health). The expression of each target gene was quantified using GAPDH.

High performance liquid chromatography (HPLC) analysis. HPLC analysis was carried out on the Waters 2695 system with a 2996 dual $\lambda$ absorbance detector (Waters Corporation). The system was equipped with the $\mathrm{XBridge}^{\mathrm{TM}} \mathrm{C} 18$ column (250x4.6 mm; $5 \mathrm{~mm}$; Waters Corporation). The mobile phase consisted of acetonitrile (solvent $\mathrm{A}$ ) and $1 \%$ acetic acid (solvent B) at a flow rate of $1.0 \mathrm{ml} / \mathrm{min}$. The injection volume of the extract was $10 \mu \mathrm{l}$. The elution phase consisted of $0-40$ min of $10-40 \%$ solvent $A$ and $90-60 \%$ of solvent B. Caffeic acid (also known as 3,4-Dihydroxybenzeneacrylic acid; cat. no. C0625; Sigma-Aldrich; Merck KGaA), an indicator component of LLT, was used as a standard. The elution was monitored at $368 \mathrm{~nm}$.

Statistical analysis. Data are presented as the mean \pm SEM. All experiments were repeated at least three times. Statistical analysis was performed using GraphPad Prism Software (version 5.01; GraphPad Software, Inc.). One-way ANOVA was used to evaluate the treatment effect, followed by Tukey's multiple-comparisons test. $\mathrm{P}<0.05$ was considered to indicate a statistically significant difference.

\section{Results}

Effects of LLT on the skin and serum of DNCB-induced $A D$ mice. To evaluate the therapeutic efficacy of LLT in the DNCB-induced AD mouse model, DNCB was applied to the dorsal skin of Balb/c mice. As shown Fig. 1B, it was confirmed that the control group exhibited erythema, edema and eczematous skin lesions on the dorsal skin, and LLT treatment improved these atopic-like symptoms. To evaluate the effect of LLT on histological characteristics, the thickness of the epidermis and dermis of the dorsal skin was measured in H\&E-stained sections (Fig. 1C). The thickness of the epidermis and dermis was increased in the DNCB-induced control group compared with the normal group $(\mathrm{P}<0.01)$. The LLT-H group exhibited significantly reduced epidermal and dermal thickness compared with the control group $(\mathrm{P}<0.01)$ (Fig. 1D). To assess the clinical symptoms of AD, the serum levels of IgE and IL-6 were measured using ELISA (Fig. 1E). The serum IL-6 levels were significantly increased in the control group compared with the normal group $(\mathrm{P}<0.01)$. The serum IL-6 levels were significantly reduced in the LLT-H groups compared with the control group $(\mathrm{P}<0.01)$. The serum IgE levels were significantly increased in the control group compared with the normal group $(\mathrm{P}<0.01)$. The serum IgE levels were significantly reduced in the LLT-L and LLT-H groups compared with the control group $(\mathrm{P}<0.01$ and $\mathrm{P}<0.05$, respectively).

Effects of LLT on histological changes in mice with $D N C B$-induced $A D$. To examine eosinophil and mast cell infiltration in the dermis, sections of dorsal skin were stained with H\&E and toluidine blue (Fig. 2A and B). Eosinophil infiltration significantly increased in the control group compared with the normal group $(\mathrm{P}<0.01)$; however, application of LLT significantly inhibited eosinophil infiltration $(\mathrm{P}<0.01$; Fig. $2 \mathrm{E})$. In addition, mast cell infiltration was significantly increased in the control group compared with the normal group $(\mathrm{P}<0.01)$, and application of LLT significantly inhibited mast cell infiltration $(\mathrm{P}<0.01$; Fig. $2 \mathrm{~F})$. The effects of LLT application on $\mathrm{CD}^{+}$and $\mathrm{CD}^{+}$cell infiltration induced by DNCB was 

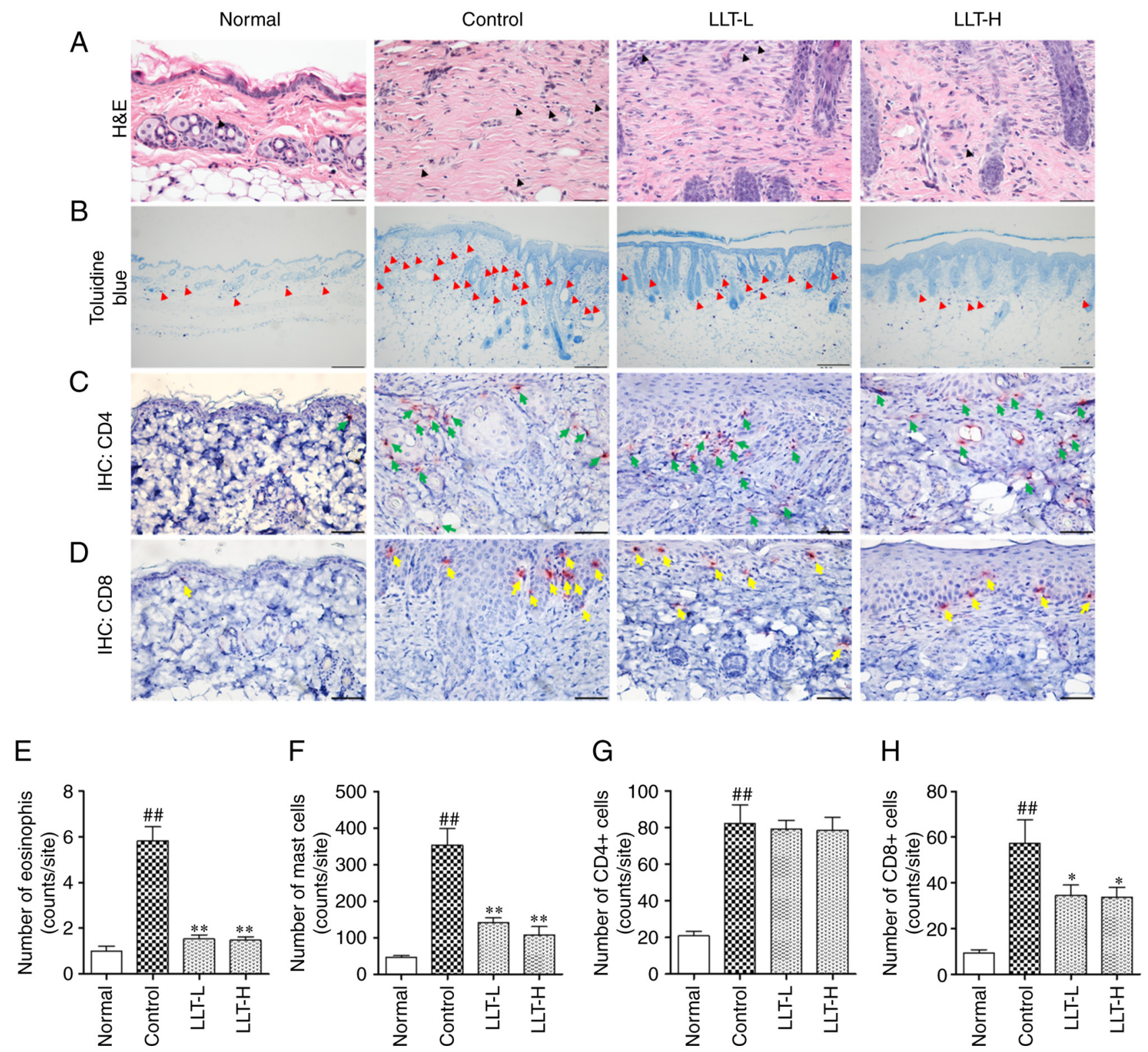

Figure 2. Effect of LLT on immune cell infiltration and the numbers of $\mathrm{CD} 4^{+}$and $\mathrm{CD} 8^{+}$cells in mice with DNCB-induced AD. Infiltration by (A) eosinophils (black arrow; magnification, $\mathrm{x} 400$; scale bar, $50 \mu \mathrm{m}$ ) and (B) mast cells (red arrow; magnification, x100; scale bar, $200 \mu \mathrm{m}$ ) in dermal lesions was examined by $\mathrm{H} \& \mathrm{E}$ and toluidine blue staining of skin sections. (C) $\mathrm{CD} 4^{+}$(green arrow) and (D) $\mathrm{CD} 8^{+}$(yellow arrow) cells were examined by IHC. Magnification, $\mathrm{x} 400$. Scale bar, $50 \mu \mathrm{m}$. The number of (E) eosinophil cells, (F) mast cells, (G) CD4 $4^{+}$cells and (H) CD8 $8^{+}$cells was counted using ImageJ software. Data represent the mean \pm SEM. $n=8$. ${ }^{\# \#} \mathrm{P}<0.01$ vs. normal grou; ${ }^{*} \mathrm{P}<0.05$ and ${ }^{* *} \mathrm{P}<0.01$ vs. control group. Normal group, vehicle-treated; control group, DNCB-sensitized; LLT-L group, DNCB + $1 \mathrm{mg} / \mathrm{kg}$ LLT; LLT-H group, DNCB + $5 \mathrm{mg} / \mathrm{kg}$ LLT. AD, atopic dermatitis; DNCB, 2,4-dinitrochlorobenzene; LLT, Lycopus lucidus Turcz; $\mathrm{H} \& \mathrm{E}$, hematoxylin and eosin; IHC, immunohistochemistry.

demonstrated by IHC staining (Fig. 2C and D). The infiltration by $\mathrm{CD}^{+}$cells increased in the control group compared with the normal group $(\mathrm{P}<0.01)$. However, application of LLT did not significantly affect $\mathrm{CD} 4^{+}$cell infiltration (Fig. 2G). In addition, the infiltration by $\mathrm{CD} 8^{+}$cells were increased in the control group compared with the normal group $(\mathrm{P}<0.01)$, and application of LLT-H significantly inhibited $\mathrm{CD} 8^{+}$cell infiltration $(\mathrm{P}<0.05$; Fig. $2 \mathrm{H})$.

Effect of LLT on the translocation and of NF- $\kappa B$ and phosphorylation of ERK and JNK in dorsal skin tissue of $A D$ mice. To investigate the anti-inflammatory role of LLT, proteins from dorsal skin tissue were extracted and the translocation of NF- $\mathrm{KB}$ and phosphorylation of ERK and JNK were measured by western blotting (Fig. 3A). The expression of NF- $\kappa \mathrm{B}$ was significantly increased in the control group compared with the normal group. In addition, application of LLT significantly inhibited the expression of NF- $\mathrm{KB}$ in a concentration-dependent manner $(\mathrm{P}<0.01$; Fig. 3B). DNCB treatment in Balb/c mice induced phosphorylation of ERK and JNK in the dorsal skin tissue, and LLT application significantly inhibited this phosphorylation $(\mathrm{P}<0.01$; Fig. $3 \mathrm{C}$ and $\mathrm{D})$.

Effect of LLT on the expression of pro-inflammatory cytokines and chemokines and the $N F-\kappa B$ signaling following $T N F-\alpha / I F N-\gamma$ stimulation in HaCaT cells. Prior to the in vitro experiment, an MTS assay was conducted to measure the toxicity of LLT in HaCaT cells. After treatment for $24 \mathrm{~h}$, it 
A
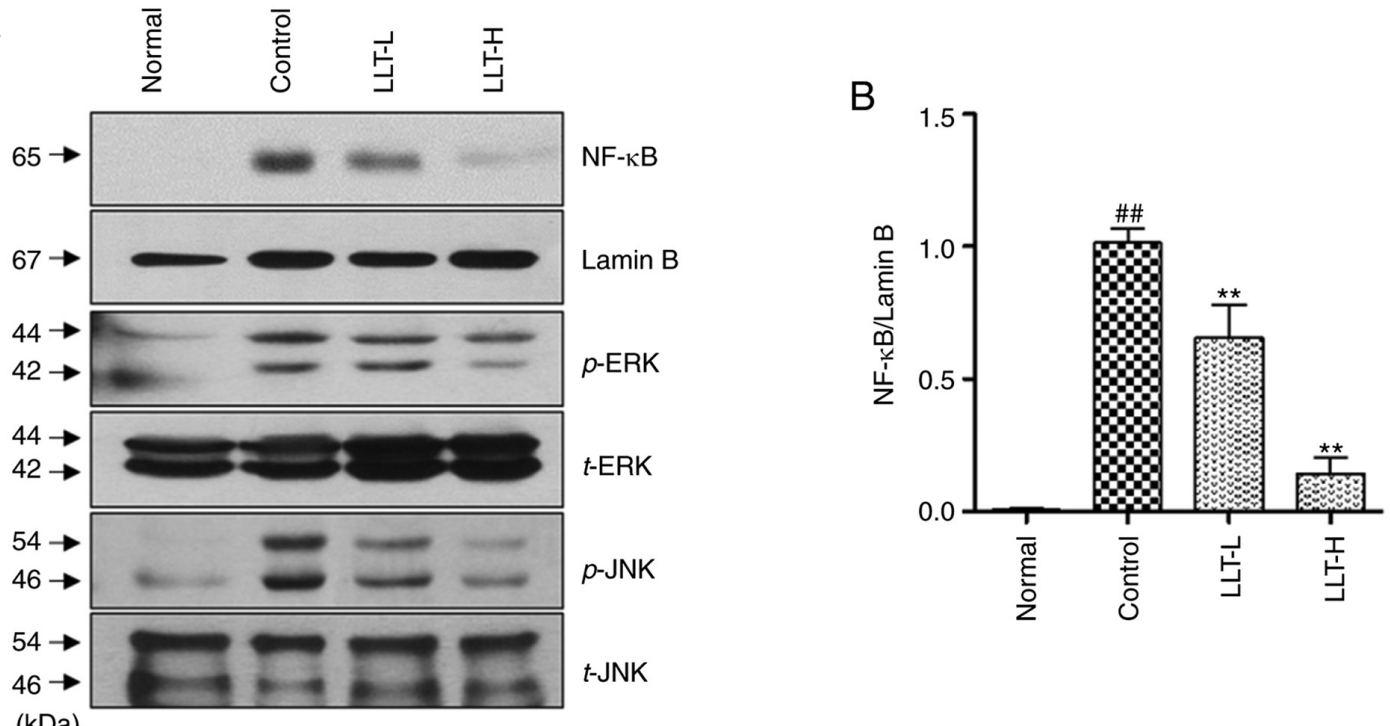

(kDa)


Figure 3. Effects of LLT on NF-kB and MAPK protein expression in BALB/c mice with DNCB-induced AD. (A) NF- $\mathrm{kB}$, p-ERK1/2 and p-JNK expression levels were examined by western blotting. (B) NF- $\mathrm{KB}$ expression level was normalized to lamin B, (C) p-ERK expression level was normalized to t-ERK and (D) p-JNK expression level was normalized to t-JNK using ImageJ software. Data represent the mean $\pm \mathrm{SEM}(\mathrm{n}=8)$. ${ }^{\# /} \mathrm{P}<0.01$ vs. normal group and ${ }^{* *} \mathrm{P}<0.01$ vs. control group. Normal group, vehicle-treated; control group, DNCB-sensitized; LLT-L group, DNCB + $1 \mathrm{mg} / \mathrm{kg}$ LLT; LLT-H group, DNCB + $5 \mathrm{mg} / \mathrm{kg}$ LLT. DNCB, 2,4-dinitrochlorobenzene; LLT, Lycopus lucidus Turcz; AD, atopic dermatitis; p-, phosphorylated; t-, total; LPS, lipopolysaccharide.

was observed that LLT did not significantly affect the viability of $\mathrm{HaCaT}$ cells (Fig. 4A). LLT and TNF- $\alpha / \mathrm{IFN}-\gamma$ stimulation were then used to treat $\mathrm{HaCaT}$ cells, and cytotoxicity was also measured. No significant change in cell viability was observed (Fig. 4B). To investigate the effect of LLT on the production of pro-inflammatory cytokines and chemokines in AD, their mRNA expression levels were measured using RT-PCR and their levels in the culture medium using ELISA. As shown in Fig. 4C and CD, the mRNA expression of TARC significantly increased following treatment with TNF- $\alpha / \mathrm{IFN}-\gamma$ in $\mathrm{HaCaT}$ cells $(\mathrm{P}<0.01)$. Moreover, the addition of $100 \mu \mathrm{g} / \mathrm{ml}$ LLT significantly reduced the expression of TARC $(\mathrm{P}<0.01)$. As shown Fig. 4E-H, the expression of GM-CSF, MCP-1, TNF- $\alpha$ and IL- $1 \beta$ in the cell medium significantly increased following treatment with TNF- $\alpha /$ IFN- $\gamma(\mathrm{P}<0.01)$, and $100 \mu \mathrm{g} / \mathrm{ml}$ LLT significantly inhibited this effect $(\mathrm{P}<0.01, \mathrm{P}<0.05, \mathrm{P}<0.01$ and $\mathrm{P}<0.01$, respectively).

The effect of LLT on the translocation and phosphorylation of NF- $\kappa \mathrm{B}$, which regulates the expression of pro-inflammatory cytokines and chemokines, was investigated. Treatment with TNF- $\alpha /$ IFN- $\gamma$ induced the expression and phosphorylation of
$\mathrm{NF}-\kappa \mathrm{B}$ in the nuclear protein fraction $(\mathrm{P}<0.01)$ and degradation of $\mathrm{I} \kappa \mathrm{B}$ in the cytoplasmic protein fraction $(\mathrm{P}<0.01)$. LLT inhibited the effects of TNF- $\alpha /$ IFN- $\gamma(\mathrm{P}<0.01)$ (Fig. 4I). Following standardization with lamin $\mathrm{B}, \mathrm{LLT}$ inhibited the expression (10 and $100 \mu \mathrm{g} / \mathrm{ml}$, both $\mathrm{P}<0.05$; Fig. 4J) and phosphorylation of $\mathrm{NF}-\kappa \mathrm{B}(1,10$ and $100 \mu \mathrm{g} / \mathrm{ml} \mathrm{P}<0.01, \mathrm{P}<0.01$ and $\mathrm{P}<0.05$, respectively; Fig. $4 \mathrm{~K}$ ). In addition, the ratio of $\mathrm{p}-\mathrm{NF}-\kappa \mathrm{B} / \mathrm{NF}-\kappa \mathrm{B}$ was significantly increased through TNF- $\alpha / \mathrm{IFN}-\gamma$ stimulation $(\mathrm{P}<0.01)$, LLT inhibited the expression $(1,10$ and $100 \mu \mathrm{g} / \mathrm{ml}$, $\mathrm{P}<0.01, \mathrm{P}<0.01$ and $\mathrm{P}<0.05$, respectively; Fig. 4L). It also inhibited the degradation of $\mathrm{I} \kappa \mathrm{B}(100 \mu \mathrm{g} / \mathrm{ml}, \mathrm{P}<0.05$; Fig. $4 \mathrm{M})$.

Effects of LLT on the expression of inflammatory cytokines, MAPKs and NF- $\kappa B$ in LPS-stimulated RAW 264.7 cells. The potential cytotoxicity of LLT was measured in RAW 264.7 cells using an MTS assay. As shown in Fig. 5A, none of the concentrations of $\operatorname{LLT}(1,10$ and $100 \mu \mathrm{g} / \mathrm{ml})$ affected the viability of the RAW 264.7 cells. The inhibitory effects of LLT on the mRNA expression of inflammatory cytokines were confirmed in LPS-stimulated RAW 264.7 cells (Fig. 5B). The expression of TNF- $\alpha$ and IFN- $\gamma$ was increased in the LPS-stimulated 


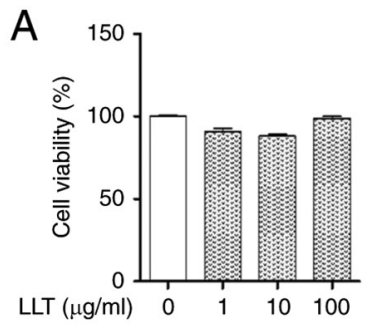

$E$

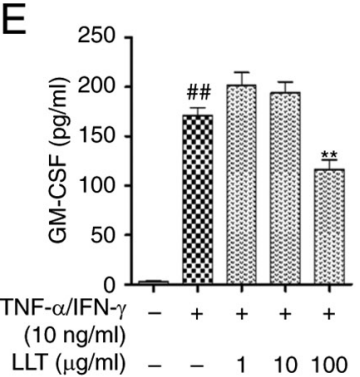

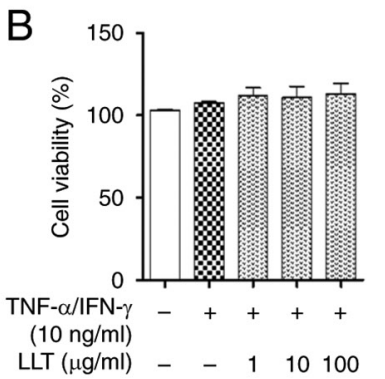

$\mathrm{F}$

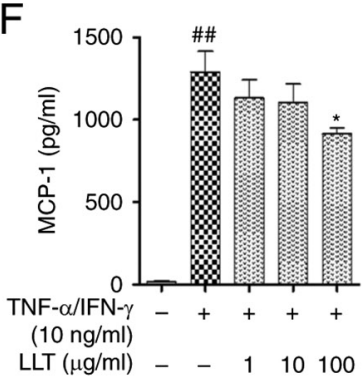

C
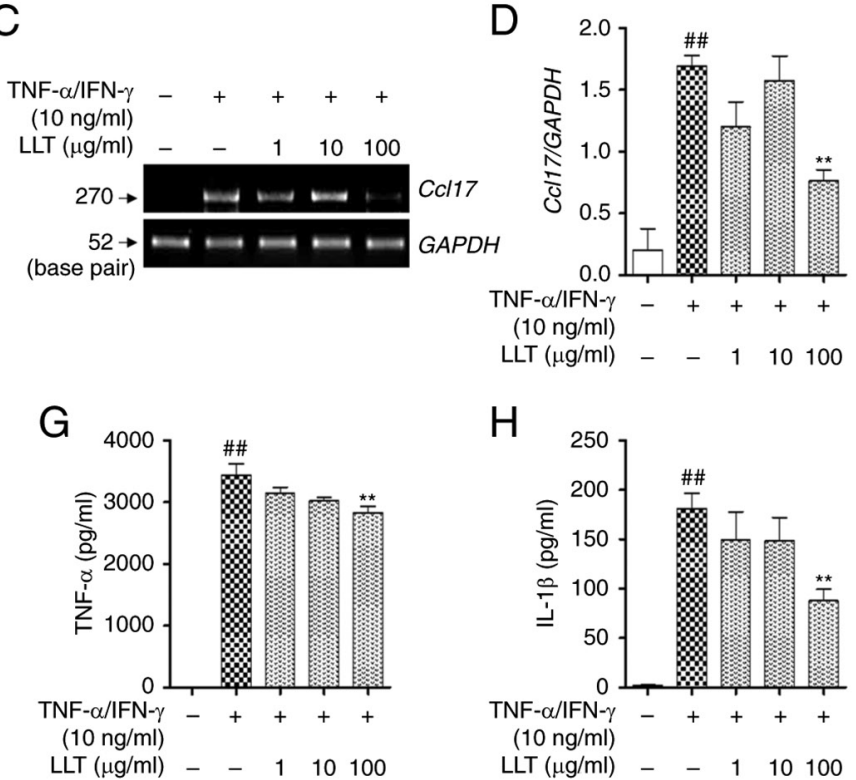

$\mathrm{H}$

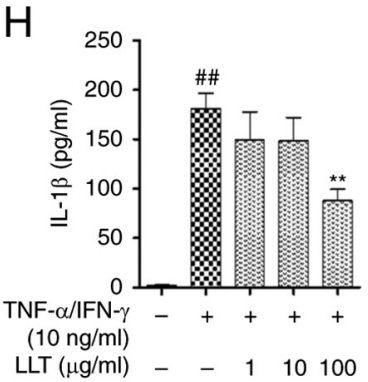

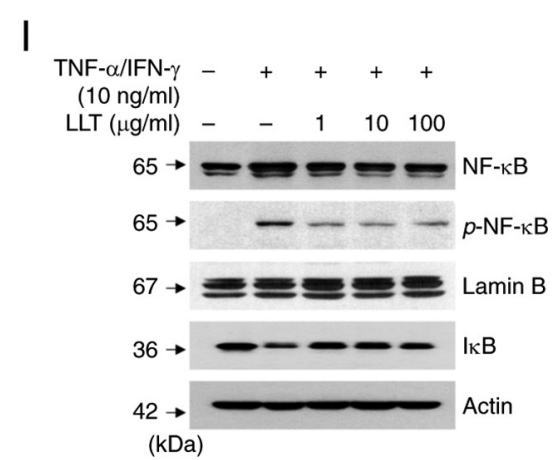
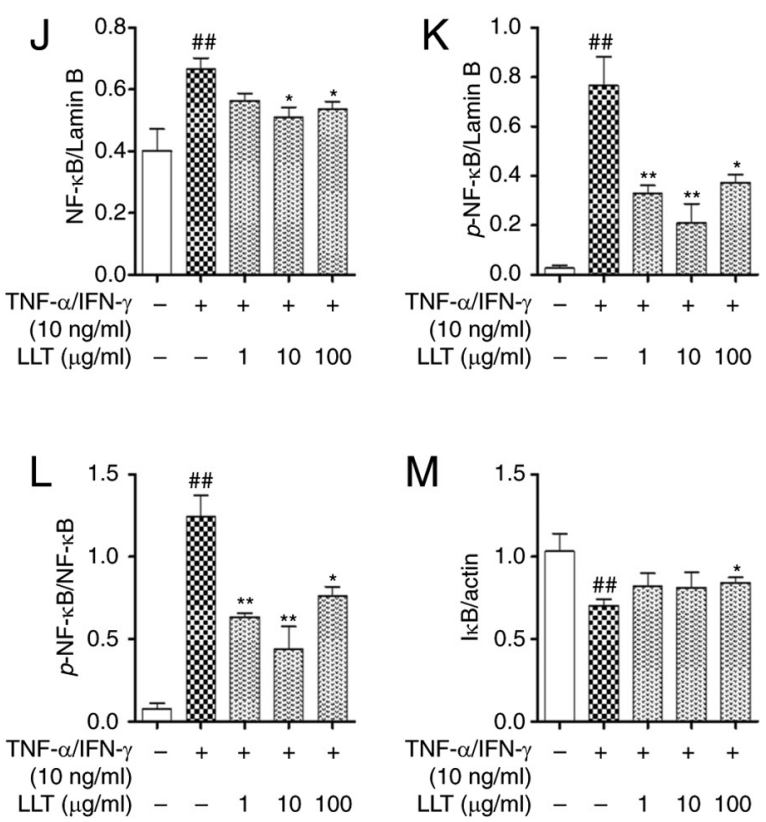



Figure 4. Effects of LLT on the expression of chemokines, pro-inflammatory cytokines and NF-kB signaling in stimulated HaCaT cells. (A) LLT cytotoxicity and (B) LLT + TNF- $\alpha /$ IFN- $\gamma$ cytotoxicity were determined using MTS assays. (C) Reverse transcription-PCR was performed to verify the effect of LLT on TARC mRNA expression. (D) TARC expression was normalized to GAPDH and quantified using ImageJ software. The effects of LLT on the expression of (E) GM-CSF, (F) MCP-1, (G) TNF- $\alpha$ and (H) IL-1 $\beta$ were analyzed by ELISA. (I) Western blotting was performed to verify the effect of LLT on the NF- $\kappa B$

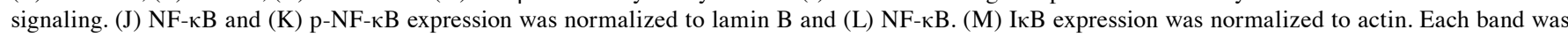
quantified using ImageJ software. Data represent the mean \pm SEM of three independent experiments. ${ }^{\# \#} \mathrm{P}<0.01$ vs. non-treated HaCaT cells. ${ }^{*} \mathrm{P}<0.05$ and ${ }^{* *} \mathrm{P}<0.01$ vs. TNF- $\alpha /$ IFN- $\gamma$ stimulated HaCaT cells. LLT, Lycopus lucidus Turcz; TARC, thymus and activation-regulated chemokine; p-, phosphorylated; GM-CSF, granulocyte-macrophage colony-stimulating factor; MCP-1, monocyte chemoattractant protein-1.

control group compared with that in the normal group $(\mathrm{P}<0.01$ and $\mathrm{P}<0.05)$. TNF- $\alpha$ expression was significantly downregulated in the LLT-treated groups (10 and $100 \mu \mathrm{g} / \mathrm{ml} ; \mathrm{P}<0.01$ and $\mathrm{P}<0.05$, respectively; Fig. 5C). LLT at concentrations of 1,10 and $100 \mu \mathrm{g} / \mathrm{ml}$ significantly reduced the levels of IFN- $\gamma$ in RAW 264.7 cells $(1,10$ and $100 \mu \mathrm{g} / \mathrm{ml} \mathrm{P}<0.05, \mathrm{P}<0.05$ and $\mathrm{P}<0.01$, respectively; Fig. 5D).

To determine the effect of LLT on the NF- $\kappa$ B pathway in RAW 264.7 cells, the effect of LLT on the expression and phosphorylation of $\mathrm{NF}-\kappa \mathrm{B}$ and degradation of $\mathrm{I} \kappa \mathrm{B}$ was investigated (Fig. 5E). Treatment with LPS induced the expression $(\mathrm{P}<0.05)$ and phosphorylation of $N F-\kappa B(P<0.01)$ in the nuclear protein and degradation of $\mathrm{I} \kappa \mathrm{B}$ in the cytoplasmic protein $(\mathrm{P}<0.05)$. The expression and phosphorylation of $\mathrm{NF}-\kappa \mathrm{B}$ in the LLT-treated groups was reduced compared with the control, but the difference was not statistically significant (Fig. 5F and G). In addition, the ratio of $\mathrm{p}-\mathrm{NF}-\kappa \mathrm{B} / \mathrm{NF}-\kappa \mathrm{B}$ was significantly increased through LPS stimulation $(\mathrm{P}<0.01)$, but no significant change was observed with LLT treatment (Fig. 5H). Although LLT appeared to inhibit the degradation 

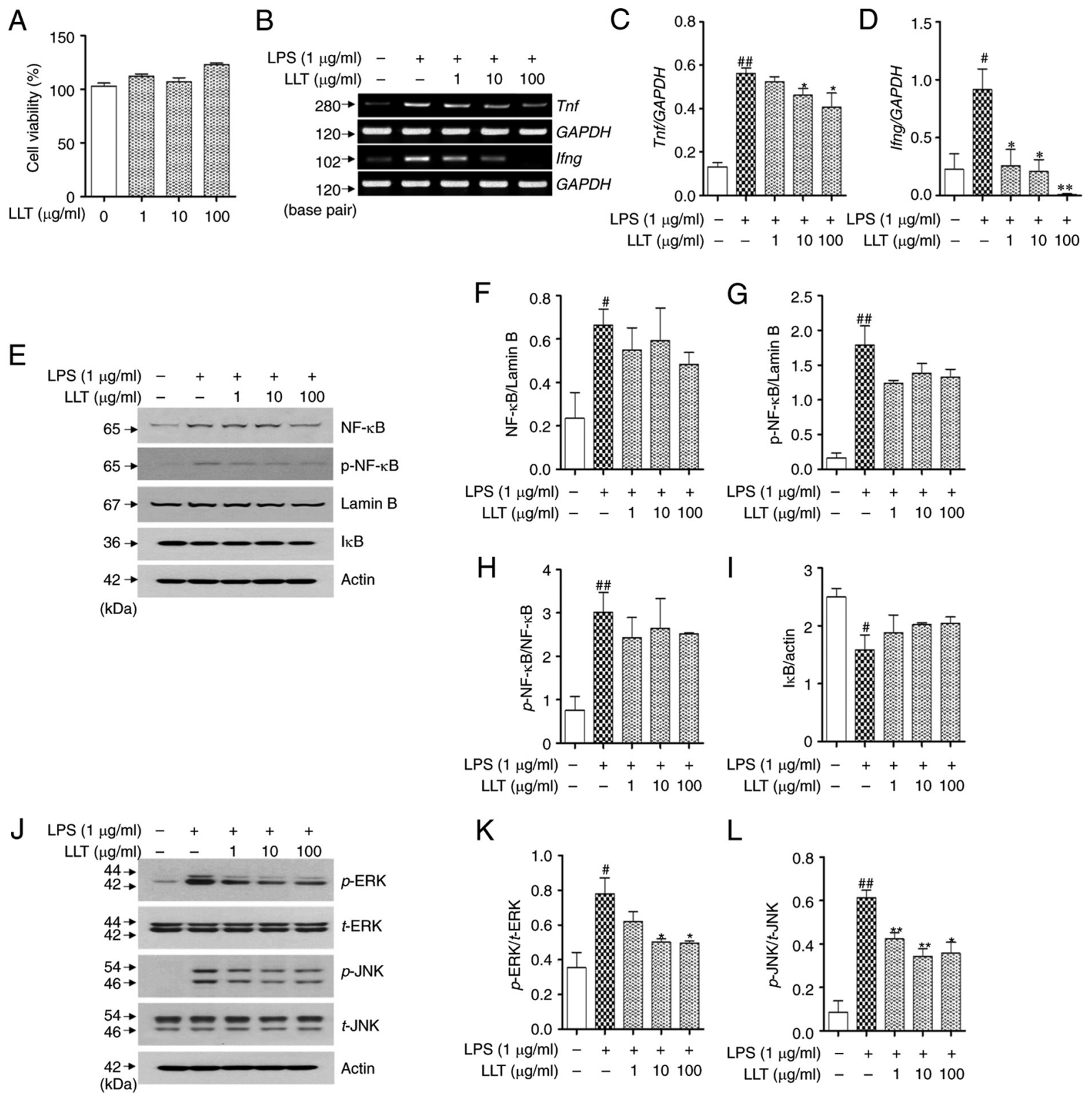

Figure 5. Effects of LLT on TNF- $\alpha$, IFN- $\gamma$, NF- $\kappa$ B signaling and MAPK expression in LPS-stimulated RAW 264.7 cells. (A) LLT cytotoxicity was determined by MTS assay. (B) Reverse-transcription PCR was performed to verify the effect of LLT on TNF- $\alpha$ and IFN- $\gamma$ mRNA expression. The expression of (C) TNF- $\alpha$ and (D) IFN- $\gamma$ was normalized to GAPDH and quantified using ImageJ software. (E) Western blotting was performed to verify the effect of LLT on the

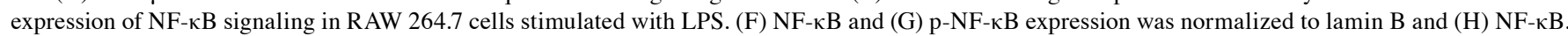
(I) IKB expression was normalized to actin. (J) The effect of LLT on ERK and JNK phosphorylation was verified by western blotting. (K and L) p-ERK and p-JNK levels were normalized to t-ERK and t-JNK, respectively, and quantified using ImageJ software. Data represent the mean \pm SEM of three independent experiments. ${ }^{\#} \mathrm{P}<0.05$ and ${ }^{\# \#} \mathrm{P}<0.01$ vs. non-treated RAW 264.7 cells. ${ }^{*} \mathrm{P}<0.05$ and ${ }^{* *} \mathrm{P}<0.01$ vs. LPS-stimulated RAW 264.7 cells. LLT, Lycopus lucidus Turcz; LPS, lipopolysaccharide; p-, phosphorylated; t-, total.

of I $\kappa$ B following LPS treatment, the difference was not significant (Fig. 5I).

To determine the effect of LLT on the MAPK pathways, the protein levels of the MAPKs ERK and JNK were assessed using western blot analysis (Fig. 5J). The levels of p-ERK and p-JNK were significantly increased in the control group compared with those in the normal group $(\mathrm{P}<0.01$ and $\mathrm{P}<0.05$, respectively). The phosphorylation of ERK and JNK was significantly reduced in the LLT treatment groups compared with the control group $(\mathrm{P}<0.05$ and $\mathrm{P}<0.01$, respectively). The level of $\mathrm{p}$-ERK was significantly decreased in the LLT-treated groups compared with the control group (10 and $100 \mu \mathrm{g} / \mathrm{ml}$; both $\mathrm{P}<0.05$; Fig. $5 \mathrm{~K}$ ). Similar to the results of $\mathrm{p}$-ERK expression, the level of p-JNK was decreased in the LLT-treated groups compared with the control group $(1,10$ and $100 \mu \mathrm{g} / \mathrm{ml} \mathrm{P}<0.01, \mathrm{P}<0.01$ and $\mathrm{P}<0.05$, respectively; Fig. $5 \mathrm{~L}$ ).

HPLC analysis. Caffeic acid has been used as a standard marker for LLT in various studies (30-32). As shown Fig. 6, the retention time of the caffeic acid was 10.62 min (Fig. 6A). The chromatographic peak of the LLT was $10.62 \mathrm{~min}$ at a wavelength of $254 \mathrm{~nm}$ (Fig. 6B). Since the peaks of LLT and caffeic acid were detected at the same time period, the LLT 

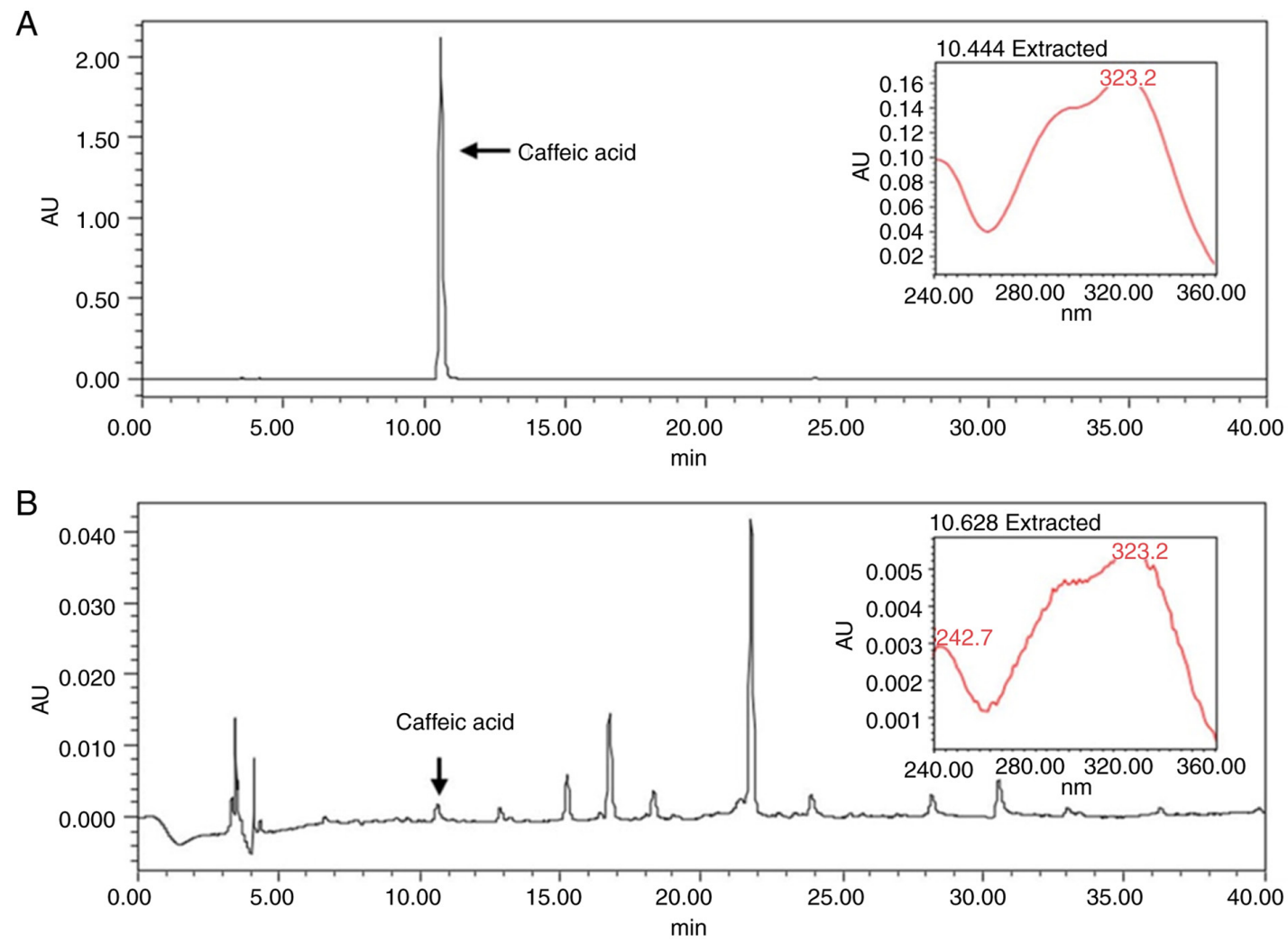

Figure 6. Representative high-performance liquid chromatograms of (A) caffeic acid and (B) LLT detected at $368 \mathrm{~nm}$. LLT, Lycopus lucidus Turcz; AU, arbitrary units.

used in this experiment was proved to be the same as that used in other studies.

\section{Discussion}

To the best of the authors' knowledge, the present study is the first to confirm the beneficial effect of LLT on DNCB-induced $\mathrm{AD}$ and its effect on the expression of cytokines and chemokines in $\mathrm{HaCaT}$ and RAW 264.7 cells. It was demonstrated that LLT inhibited DNCB-induced hyperkeratosis in the epidermis and dermis, and infiltration by eosinophils, mast cells and $\mathrm{CD} 8^{+}$cells. LLT also inhibited the expression of IgE and IL-6 in the serum, and the phosphorylation of MAPK and NF- $\mathrm{BB}$ in the skin tissues. In addition, LLT inhibited the expression of inflammatory chemokines and cytokines in HaCaT and RAW 264.7 cells. Taken together, these findings confirmed that LLT has the potential of becoming a new alternative AD treatment. Balb/c mice, in which AD was induced through DNCB stimulation, are characterized by a Th2-dominated immune response and are widely used in the field of Immunology (33). In addition, DNCB was found to promote the expression of various cytokines (34) and chemokines (35) that induce AD. $\mathrm{HaCaT}$ cells are a naturally immortalized line of human keratinocytes. These cells are widely used in skin biology and differentiation studies. RAW 264.7 cells are macrophages derived from Abelson leukemia virus-infected mice, and they are used in various studies to verify the effects on the inflammatory response (36). LPS is a gram-negative bacterium, which increases various inflammatory cytokines and a large amount of nitric oxide (NO) to cause tissue damage, edema and inflammatory response (37). Therefore, the LPS-induced RAW 264.7 cell model has been used in various studies to examine the mechanism of $\operatorname{AD}(38,39)$.

Skin thickening is a notable clinical symptom of AD (40,41). Continuous allergic and inflammatory responses may result in hardened and thickened skin (42). In the present study, LLT inhibited the thickening of the epidermis and dermis, indicating that LLT exerts an inhibitory effect on hyperkeratosis and alleviates skin thickening, which is one of the main symptoms of AD. The cytokines secreted by Th1 and Th2 cells promote the development of AD (43). Th2-cell allergic inflammation predominates in the acute stage of AD, resulting in increased IL- 6 and IgE expression, whereas Th1-cell inflammation predominates in the chronic stage of $\mathrm{AD}$, resulting in increased expression of IFN- $\gamma$ and TNF- $\alpha(5,44,45)$. Th2 cells activate B cells, which produce $\operatorname{IgE}(46)$. IgE binds to the $\operatorname{IgE}$ receptor, FceRI, and initiates the activation of mast cells, leading to the release of histamine and other mediators of inflammation $(47,48)$. In the present study, the levels of IgE and IL-6 were significantly increased in the serum of mice with DNCB-induced AD, whereas LLT decreased the production of IgE and IL-6.

$\mathrm{AD}$ is associated with high $\mathrm{IgE}$ levels and infiltration by inflammatory cells, such as mast cells and eosinophils (49). The majority of patients with AD are pathologically characterized by infiltration of the skin lesions by eosinophils and mast cells $(50,51)$. The activation of mast cells has been associated with allergic inflammation and the expression of various inflammatory mediators, including histamine, which induces AD-like skin lesions $(52,53)$. Eosinophils are cells of 
the immune system, which, together with mast cells, act as mediators of allergic reactions (13). Mast cells and eosinophils are recruited and activated in the inflamed dermis, where they play a major role in aggravating allergic skin conditions (54). Research has shown that these cells modulate pruritus in AD and induce allergic inflammation $(55,56)$. Increased numbers of eosinophils and mast cells are a characteristic feature of $\mathrm{AD}$ in both humans and DNCB-induced AD mice (57-59). To examine the effects of LLT on the infiltration of eosinophils and mast cells, the present study performed H\&E and toluidine blue staining of dorsal skin tissues obtained from DNCB-induced AD mice. It was observed that LLT decreased the number of eosinophils and mast cells in the skin of AD mice, indicating that LLT may inhibit the infiltration of the dermis by mast cells and eosinophils by suppressing IgE and the release of pro-inflammatory cytokines.

$\mathrm{CD}^{+} \mathrm{T}$ cells (Th cells) induce humoral immunity by acting on specific $\mathrm{B}$ lymphocytes to promote responses to antigens $(60,61)$. Humoral immunity is an antigen-antibody reaction caused by the activation of $\mathrm{B}$ cells and $\mathrm{T}$ cells by $\mathrm{CD} 4^{+} \mathrm{T}$ cells and the mechanism is as follows. The antigen-memory $\mathrm{CD} 4^{+}$ $\mathrm{T}$ cells induce the differentiation of B cells. Differentiated B cells meet with $\mathrm{T}$ cells to form antibodies in $\mathrm{T}$ cells and these antibodies circulate in body fluids and cause antigen/antibody reactions (62). In a normal allergic environment, Th2 cells induce the production of Th2 cytokines responsible for the expression of allergen-specific $\operatorname{IgE}(63) . \mathrm{CD}^{+}$cells (cytotoxic/suppressor $\mathrm{T}$ cells) release toxic substances, such as perforin, granzyme and granulicin, that can directly target antigen-bearing cells, and when stimulated, Th1 cells are activated to induce the expression of inflammatory cytokines such as TNF- $\alpha$ (64); therefore, the numbers of $\mathrm{CD}^{+}$and $\mathrm{CD}^{+}$ cells are important indicators for measuring the immune function (65). In the present study, LLT reduced the number of $\mathrm{CD}^{+}$cells in the skin tissue with DNCB-induced AD, but did not significantly affect the number of $\mathrm{CD} 4^{+}$cells. Because $\mathrm{CD} 4^{+}$cells are not under the control of LLT in the present study, the reason why the expression of $\operatorname{IgE}$ mediated by $\mathrm{Th} 2$ cytokines is suppressed may be related to the suppression of IL-6 expression. A previous study has shown that the expression of IL-6 upregulates the expression of $\operatorname{IgE}(66)$. From this study, the IgE expression inhibitory effect of LLT is hypothesized to be suppressed through IL-6, not through CD4 ${ }^{+}$cells. In addition, the expression of $\operatorname{IgE}$ induces the degradation of the mast cells to express various inflammatory cytokines. In this study, the invasion of the mast cells in the tissue was inhibited, as evidenced by toluidine blue staining. Therefore, following the results of these studies, it was demonstrated that the infiltration of mast cells was induced by the expression of IgE and that LLT inhibited them. Combining the experimental results of serum and tissue analysis, these results indicated that the inhibition of the inflammatory response by LLT in AD is mediated through inhibition of $\mathrm{CD}^{+}$cell, but not $\mathrm{CD}^{+}$cell infiltration.

The activation of NF- $\kappa \mathrm{B}$ is a key step in the progression of inflammatory skin conditions $(15,67,68)$. Therefore, the inhibition of the NF- $\kappa \mathrm{B}$ expression may represent a target for the treatment of inflammatory diseases, including AD (69). The activation of MAPK signaling plays a major role in $\mathrm{NF}-\kappa \mathrm{B}$ activation $(70,71)$. The MAPK (ERK/1/2 and JNK) signaling pathway plays an important role in the proliferation, degranulation and activation of diverse immune cells (72). In the present study, LLT inhibited the expression of $\mathrm{NF}-\kappa \mathrm{B}$ in the dorsal skin tissues obtained from mice with DNCB-induced AD. Furthermore, LLT inhibited the expression and phosphorylation of NF- $\kappa$ B in $\mathrm{HaCaT}$ cells induced by TNF- $\alpha / \mathrm{IFN}-\gamma$ in nuclear protein and it also inhibited the degradation of $\mathrm{I} \kappa \mathrm{B}$ in the cytoplasmic protein. In addition, LLT treatment appeared to show a positive effect on the NF- $\kappa \mathrm{B}$ pathway in RAW 264.7 cells stimulated with LPS, although the difference was not significant. These results indicated that the effect of LLT may be mediated through inhibition of expression and phosphorylation of $\mathrm{NF}-\kappa \mathrm{B}$, a target in $\mathrm{AD}$ treatment. In addition, LLT significantly inhibited the phosphorylation of ERK and JNK in tissues and phosphorylation of LPS-induced MAPK pathway-related proteins in RAW 264.7 cells.

MAPK and NF- $\mathrm{NB}$ signaling induce AD through the expression of various pro-inflammatory cytokines and chemokines (73). TARC is a representative Th2 chemokine that acts on the $\mathrm{C}-\mathrm{C}$ chemokine receptor 4 expressed on $\mathrm{T}$ cells to induce the migration and invasion of $\mathrm{Th} 2$ cells in inflammatory lesions (74). TARC is produced by a variety of cells, including endothelial cells, dendritic cells and keratinocytes. In AD, TARC induces integrin-dependent adhesion and passage of $\mathrm{T}$ cells through the blood vessel wall, acting in the first stage of T-cell recruitment to the lesion (75). The expression of TARC is high in the basal layer of the epidermis in skin lesions (74), and serum TARC levels are markedly elevated in patients with $\mathrm{AD}$, which is directly proportional to the severity of the symptoms (76) and may be used as an index of AD severity. In the present study, LLT was shown to inhibit TARC expression in $\mathrm{HaCaT}$ cells stimulated with TNF- $\alpha / \mathrm{IFN}-\gamma$. GM-CSF is a cytokine secreted by lymphocytes, and its expression is increased in chronic AD, which is known to inhibit apoptosis and promote survival of lymphocytes, causing chronic inflammation of skin lesions (77). MCP-1 is a member of the CC family of chemokines and it serves as a chemotactic factor for monocytes. MCP-1 has been demonstrated to affect the migration and invasion of monocytes, macrophages, memory $\mathrm{T}$ cells and natural killer cells, and an increase in MCP-1 has been observed in studies on patients with chronic and idiopathic urticaria, a chronic inflammatory skin disease (78). In the present study, LLT inhibited GM-CSF and MCP-1 expression in $\mathrm{HaCaT}$ cells stimulated by TNF- $\alpha / \mathrm{IFN}-\gamma$.

When HaCaT cells are exposed to stress, cytokines, such as TNF- $\alpha$ and IL-1 $\beta$, activate several inflammation-related cell signaling pathways (79). TNF- $\alpha$ is a pro-inflammatory cytokine that is involved in the initiation of inflammatory reactions. TNF- $\alpha$ regulates the lipid barrier function of the skin, either by acting alone or in combination with Th2 cytokines, and is also involved in the proliferation of thymic stromal lymphopoietin (80). IL-1 $\beta$ is mainly secreted by activated mononuclear phagocytic cells (81). As a lymphocyte-activating factor, IL-1 $\beta$ promotes the activation and proliferation of $\mathrm{CD}^{+} \mathrm{T}$ lymphocytes and secretion of IFN- $\gamma$, and activates vascular endothelial cells to cause leukocyte adhesion (82). Therefore, IL-1 $\beta$ plays an important role in the inflammatory process and is involved in type I hypersensitivity reactions in allergic diseases (11). In the present study, LLT inhibited the expression of TNF- $\alpha$ and IL- $1 \beta$ in stimulated HaCaT cells, and 
suppressed the expression of TNF- $\alpha$ and IFN $-\gamma$ in stimulated RAW 264.7 cells. Collectively, these experimental results indicate that LLT may suppress the expression of chemokines and inflammatory cytokines by inhibiting the expression of MAPKs and NF- $\kappa$ B signaling. Finally, LLT may improve AD by increasing the thickness of the skin barrier and inhibiting infiltration by eosinophils and mast cells.

This study has the following limitations. First, in an in vitro assay, it was verified the NF- $\mathrm{NB}$ pathway in $\mathrm{HaCaT}$ cells and RAW 264.7 cells. LLT showed a significant inhibitory effect on the expression and phosphorylation of $\mathrm{NF}-\kappa \mathrm{B}$ in $\mathrm{HaCaT}$ cells, and showed a positive effect compared to the induced group, although the difference was not significant in RAW 264.7 cells. However, in the study of NF- $\mathrm{B}$ in animal tissues, the expression of $\mathrm{NF}-\kappa \mathrm{B}$ was only measured in the nuclear protein fraction. As a result, the role of the $N F-\kappa B$ pathway in $A D$ remains unconfirmed. In future studies, additional research on $\mathrm{NF}-\kappa \mathrm{B}$ phosphorylation or I $\mathrm{B}$ degradation may provide further insight into the ability of LLT to inhibit AD. Moreover, this study verified the anti-atopic effect of LLT, a herbal medicine, but it is unclear which ingredients in LLT play an anti-atopic role. In previous study, LLT was shown to possess various active ingredients such as schizotenuin A, 3-O-(caffeoyl)-rosmarinic acid, rosmarinic acid ethyl ester, apigenin, acacetin, acacetin-7-O-b-D-glucuronopyranoside, luteolin, scutellarin and hispidulinc (83). Among these ingredients, rosmarinic acid improves the scoring atopic dermatitis (SCORAD) index (a standardized method for the severity of atopic dermatitis in the European atopic dermatitis task force consensus report) (84) and skin moisture index in clinical trials (85), luteolin was effective in treating skin diseases by inhibiting the expression of pro-inflammatory mediators in the $\mathrm{NF}-\kappa \mathrm{B}$ pathway (86). In addition, hispidulin inhibited $\mathrm{AD}$ by regulating the expression of IL-1 $\beta$, IL-6, IL-8 and chemokine C-C (87). However, the pharmacological effects of the remaining ingredients on atopic diseases have not yet been verified. In the future, directly separating the components contained in LLT, may further confirm and improve our understanding of the pharmacological effect of LLT in each atopic disease.

\section{Acknowledgements}

Not applicable.

\section{Funding}

This work was supported by a grant from The National Research Foundation of Korea (NRF) funded by the Korean Government [Ministry of Science and ICT (MSIT); grant no. 2020R1A2C2005836].

\section{Availability of data and materials}

The datasets used and/or analyzed during the current study are available from the corresponding author on reasonable request.

\section{Authors' contributions}

HSJ designed the experiments. EYK, GYM and SH performed the in vivo experiments. GYM, JHK, MK and EJK performed the in vitro experiments. YS, HSJ and JHP performed the data analysis. GYM wrote the manuscript. GYM and HSJ confirm the authenticity of the raw data in this manuscript. All the authors have read and approved the final manuscript.

\section{Ethics approval and consent to participate}

All animal experiments were performed with the approval of The Institutional Animal Care and Use Committee of Kyung Hee University [approval no. KHUASP (SE)-15-116].

\section{Patient consent for publication}

Not applicable.

\section{Competing interests}

The authors declare that they have no competing interests.

\section{References}

1. Choi JH, Kim HG, Jin SW, Han EH, Khanal T, Do MT, Hwang YP, Choi JM, Chun SS, Chung YC, et al: Topical application of Pleurotus eryngii extracts inhibits 2,4-dinitrochlorobenzene-induced atopic dermatitis in NC/Nga mice by the regulation of Th1/Th2 balance. Food Chem Toxicol 53: 38-45, 2013.

2. Johansson SG, Hourihane JO, Bousquet J, Bruijnzeel-Koomen C, Dreborg S, Haahtela T, Kowalski ML, Mygind N, Ring J, van Cauwenberge $\mathrm{P}$, et al: A revised nomenclature for allergy. An EAACI position statement from the EAACI nomenclature task force. Allergy 56: 813-824, 2001.

3. Cookson W: The immunogenetics of asthma and eczema: A new focus on the epithelium. Nat Rev Immunol 4: 978-988, 2004.

4. Denby KS and Beck LA: Update on systemic therapies for atopic dermatitis. Curr Opin Allergy Clin Immunol 12: 421-426, 2012.

5. Bieber T: Atopic dermatitis. N Engl J Med 358: 1483-1494, 2008.

6. Kim JH, Kim MH, Yang G, Huh Y, Kim SH and Yang WM: Effects of topical application of Astragalus membranaceus on allergic dermatitis. Immunopharmacol Immunotoxicol 35: 151-156, 2013.

7. Yuan XY, Ma HM, Li RZ, Wang RY, Liu W and Guo JY: Topical application of aloperine improves 2,4-dinitrofluorobenzene-induced atopic dermatitis-like skin lesions in NC/Nga mice. Eur J Pharmacol 658: 263-269, 2011.

8. Kim EC, Lee HS, Kim SK, Choi MS, Lee S, Han JB, An HJ, Um JY, Kim HM, Lee NY, et al: The bark of Betula platyphylla var. Japonica inhibits the development of atopic dermatitis-like skin lesions in NC/Nga mice. J Ethnopharmacol 116: 270-278, 2008.

9. Watanabe H, Unger M, Tuvel B, Wang B and Sauder DN: Contact hypersensitivity: The mechanism of immune responses and $\mathrm{T}$ cell balance. J Interferon Cytokine Res 22: 407-412, 2002.

10. Bieber T, Cork M and Reitamo S: Atopic dermatitis: A candidate for disease-modifying strategy. Allergy 67: 969-975, 2012.

11. Brandt EB and Sivaprasad U: Th2 cytokines and atopic dermatitis. J Clin Cell Immunol 2: 110, 2011.

12. Tokura Y: Extrinsic and intrinsic types of atopic dermatitis. J Dermatol Sci 58: 1-7, 2010.

13. Liu FT, Goodarzi H and Chen HY: IgE, mast cells, and eosinophils in atopic dermatitis. Clin Rev Allergy Immunol 41: 298-310, 2011.

14. Seitz CS, Lin Q, Deng $H$ and Khavari PA: Alterations in NF-kappaB function in transgenic epithelial tissue demonstrate a growth inhibitory role for NF-kappaB. Proc Natl Acad Sci USA 95: 2307-2312, 1998.

15. Smahi A, Courtois G, Rabia SH, Doffinger R, Bodemer C, Munnich A, Casanova JL and Israel A: The NF-kappaB signalling pathway in human diseases: From incontinentia pigmenti to ectodermal dysplasias and immune-deficiency syndromes. Hum Mol Genet 11: 2371-2375, 2002.

16. Kataoka Y: Thymus and activation-regulated chemokine as a clinical biomarker in atopic dermatitis. J Dermatol 41: 221-229, 2014. 
17. Emile JF, Fraitag S, Andry P, Leborgne M, Lellouch-Tubiana A and Brousse N: Expression of GM-CSF receptor by Langerhans cell histiocytosis cells. Virchows Arch 427: 125-129, 1995.

18. Rajagopalan LE, Burkholder JK, Turner J, Culp J, Yang NS and Malter JS: Granulocyte-macrophage colony-stimulating factor mRNA stabilization enhances transgenic expression in normal cells and tissues. Blood 86: 2551-2558, 1995.

19. Breuhahn K, Mann A, Muller G, Wilhelmi A, Schirmacher P, Enk A and Blessing M: Epidermal overexpression of granulocyte-macrophage colony-stimulating factor induces both keratinocyte proliferation and apoptosis. Cell Growth Differ 11: 111-121, 2000.

20. Pastore S, Fanales-Belasio E, Albanesi C, Chinni LM, Giannetti A and Girolomoni G: Granulocyte macrophage colony-stimulating factor is overproduced by keratinocytes in atopic dermatitis Implications for sustained dendritic cell activation in the skin. J Clin Invest 99: 3009-3017, 1997

21. Kaburagi Y, Shimada Y, Nagaoka T, Hasegawa M, Takehara K and Sato S: Enhanced production of CC-chemokines (RANTES MCP-1, MIP-1alpha, MIP-1beta, and eotaxin) in patients with atopic dermatitis. Arch Dermatol Res 293: 350-355, 2001.

22. Klonowska J, Glen J, Nowicki RJ and Trzeciak M: New cytokines in the pathogenesis of atopic dermatitis-new therapeutic targets. Int J Mol Sci 19: 3086, 2018.

23. Leung DY: Atopic dermatitis: New insights and opportunities for therapeutic intervention. J Allergy Clin Immunol 105: 860-876, 2000.

24. Tan Q, Yang H, Liu E and Wang H: P38/ERK MAPK signaling pathways are involved in the regulation of filaggrin and involucrin by IL17. Mol Med Rep 16: 8863-8867, 2017.

25. Cui HZ, Oh HC, Li X, Lee YJ, Cho KW, Kang DG and Lee HS Ethanol extract of Lycopus lucidus elicits positive inotropic effect via activation of $\mathrm{Ca}_{2}{ }^{+}$entry and $\mathrm{Ca} 2^{+}$release in beating rabbit atria. J Med Food 16: 633-640, 2013

26. Jeong DW, Kim EY, Kim JH, Lee B, Hong S, Park JH, Jung HS and Sohn Y: Lycopus lucidus Turcz Inhibits the Osteoclastogenesis in RAW 264.7 Cells and Bone Loss in Ovariectomized Rat Model. Evid Based Complement Alternat Med 2019: 3231784, 2019.

27. Shin TY, Kim SH, Suk K, Ha JH, Kim I, Lee MG, Jun CD, Kim SY, Lim JP, Eun JS, et al: Anti-allergic effects of Lycopus lucidus on mast cell-mediated allergy model. Toxicol Appl Pharmacol 209: 255-262, 2005

28. Woo ER and Piao MS: Antioxidative constituents from Lycopus lucidus. Arch Pharm Res 27: 173-176, 2004.

29. Lee YJ, Kang DG, Kim JS and Lee HS: Lycopus lucidus inhibits high glucose-induced vascular inflammation in human umbilical vein endothelial cells. Vascul Pharmacol 48: 38-46, 2008.

30. Kim KY, Oh TW, Ma JY and Park KI: Ethanol extract of Lycopus lucidus Turcz. ex benth inhibits metastasis by downregulation of Runx-2 in mouse colon cancer cells. Evid Based Complement Alternat Med 2018: 9513290, 2018.

31. Ren Q, Ding L, Sun SS, Wang HY and Qu L: Chemical identification and quality evaluation of Lycopus lucidus Turcz by UHPLC-Q-TOF-MS and HPLC-MS/MS and hierarchical clustering analysis. Biomed Chromatogr 31: 2017.

32. Slusarczyk S, Hajnos M, Skalicka-Woźniak K and Matkowski A Antioxidant activity of polyphenols from Lycopus lucidus Turcz. Food Chem 113: 134-138, 2009.

33. Kwon B, Hong SY, Kim EY, Kim JH, Kim M, Park JH, Sohn Y and Jung HS: Effect of cone of pinus densiflora on DNCB-induced allergic contact dermatitis-like skin lesion in Balb/c Mice. Nutrients 13: 839, 2021.

34. Zhang EY, Chen AY and Zhu BT: Mechanism of dinitrochlorobenzene-induced dermatitis in mice: Role of specific antibodies in pathogenesis. PLoS One 4: e7703, 2009.

35. Han MH, Yoon WK, Lee H, Han SB, Lee K, Park SK, Yang KH, Kim HM and Kang JS: Topical application of silymarin reduces chemical-induced irritant contact dermatitis in $\mathrm{BALB} / \mathrm{c}$ mice. Int Immunopharmacol 7: 1651-1658, 2007.

36. Raschke WC, Baird S, Ralph P and Nakoinz I: Functional macrophage cell lines transformed by Abelson leukemia virus. Cell 15 261-267, 1978.

37. Bhardwaj M, Sali VK, Mani S and Vasanthi HR: Neophytadiene from turbinaria ornata suppresses LPS-induced inflammatory response in RAW 264.7 macrophages and sprague dawley rats. Inflammation 43: 937-950, 2020.

38. Lee DH, Park JK, Choi J, Jang H and Seol JW: Anti-inflammatory effects of natural flavonoid diosmetin in IL-4 and LPS-induced macrophage activation and atopic dermatitis model. Int Immunopharmacol 89: 107046, 2020.
39. Lee HN, Shin SA, Choo GS, Kim HJ, Park YS, Kim BS, Kim SK, Cho SD, Nam JS, Choi CS, et al: Antiinflammatory effect of quercetin and galangin in LPS-stimulated RAW264.7 macrophages and DNCB-induced atopic dermatitis animal models. Int J Mol Med 41: 888-898, 2018.

40. Choi JK, Oh HM, Lee S, Kwon TK, Shin TY, Rho MC and Kim SH: Salvia plebeia suppresses atopic dermatitis-like skin lesions. Am J Chin Med 42: 967-985, 2014.

41. Proksch E, Folster-Holst R and Jensen JM: Skin barrier function, epidermal proliferation and differentiation in eczema. J Dermatol Sci 43: 159-169, 2006.

42. Yarbrough KB, Neuhaus KJ and Simpson EL: The effects of treatment on itch in atopic dermatitis. Dermatol Ther 26: 110-119, 2013.

43. Wang Q, Gao S, Wu GZ, Yang N, Zu XP, Li WC, Xie N, Zhang RR, Li CW, Hu ZL and Zhang WD: Total sesquiterpene lactones isolated from Inula helenium L. attenuates 2, 4-dinitrochlorobenzene-induced atopic dermatitis-like skin lesions in mice. Phytomedicine 46: 78-84, 2018

44. Kim JE, Kim JS, Cho DH and Park HJ: Molecular mechanisms of cutaneous inflammatory disorder: Atopic dermatitis. Int J Mol Sci 17: 1234, 2016

45. Cesare AD, Meglio PD and Nestle FO: A role for Th17 cells in the immunopathogenesis of atopic dermatitis? J Invest Dermatol 128: 2569-2571, 2008.

46. Deo SS, Mistry KJ, Kakade AM and Niphadkar PV: Role played by Th2 type cytokines in IgE mediated allergy and asthma. Lung India 27: 66-71, 2010.

47. Stone KD, Prussin C and Metcalfe DD: IgE, mast cells, basophils, and eosinophils. J Allergy Clin Immunol 125 (Suppl 2): S73-S80, 2010

48. Metcalfe DD, Baram D and Mekori YA: Mast cells. Physiol Rev 77: 1033-1079, 1997.

49. Inagaki N, Shiraishi N, Igeta K, Itoh T, Chikumoto $\mathrm{T}$, Nagao M, Kim JF and Nagai H: Inhibition of scratching behavior associated with allergic dermatitis in mice by tacrolimus, but not by dexamethasone. Eur J Pharmacol 546: 189-196, 2006

50. Plager DA, Henke SA, Matsuwaki Y, Madaan A, Squillace DL, Dierkhising RA and Kita H: Pimecrolimus reduces eosinophil activation associated with calcium mobilization. Int Arch Allergy Immunol 149: 119-126, 2009.

51. Fujii Y, Takeuchi H, Sakuma S, Sengoku T and Takakura S: Characterization of a 2,4-dinitrochlorobenzene-induced chronic dermatitis model in rats. Skin Pharmacol Physiol 22: 240-247, 2009.

52. Galli SJ and Tsai M: IgE and mast cells in allergic disease. Nat Med 18: 693-704, 2012

53. Sismanopoulos N, Delivanis DA, Alysandratos KD, Angelidou A, Therianou A, Kalogeromitros D and Theoharides TC: Mast cells in allergic and inflammatory diseases. Curr Pharm Des 18: 2261-2277, 2012

54. Won TJ, Kim B, Lee Y, Bang JS, Oh ES, Yoo JS, Hyung KE, Yoon J, Hwang S, Park ES, et al: Therapeutic potential of Lactobacillus plantarum CJLP133 for house-dust mite-induced dermatitis in NC/Nga mice. Cell Immunol 277: 49-57, 2012.

55. Ikoma A, Steinhoff M, Stander S, Yosipovitch G and Schmelz M The neurobiology of itch. Nat Rev Neurosci 7: 535-547, 2006.

56. Paus R, Schmelz M, Biro T and Steinhoff M: Frontiers in pruritus research: Scratching the brain for more effective itch therapy. J Clin Invest 116: 1174-1186, 2006

57. James EA and Kwok WW: Autoreactive CD4(+) T cells in patients with atopic dermatitis. J Allergy Clin Immunol 128: 100-101, 2011.

58. Murota H, El-latif MA, Tamura T, Amano T and Katayama I: Olopatadine hydrochloride improves dermatitis score and inhibits scratch behavior in NC/Nga mice. Int Arch Allergy Immunol 153: 121-132, 2010.

59. Yamanaka K and Mizutani H: The role of cytokines/chemokines in the pathogenesis of atopic dermatitis. Curr Probl Dermatol 41: 80-92, 2011.

60. Barcena $\mathrm{J}$ and Blanco E: Design of novel vaccines based on virus-like particles or chimeric virions. Subcell Biochem 68 631-665, 2013

61. Eisenbarth SC, Baumjohann D, Craft J, Fazilleau N, Ma CS Tangye SG, Vinuesa CG and Linterman MA: $\mathrm{CD}^{+} \mathrm{T}$ cells that help B cells-a proposal for uniform nomenclature. Trends Immunol 42: 658-669, 2021.

62. Mitchison NA: T-cell-B-cell cooperation. Nat Rev Immunol 4: 308-312, 2004 
63. Gri G, Piconese S, Frossi B, Manfroi V, Merluzzi S, Tripodo C, Viola A, Odom S, Rivera J, Colombo MP and Pucillo CE: $\mathrm{CD} 4{ }^{+} \mathrm{CD} 25^{+}$regulatory $\mathrm{T}$ cells suppress mast cell degranulation and allergic responses through OX40-OX40L interaction. Immunity 29: 771-781, 2008.

64. Fong TA and Mosmann TR: Alloreactive murine $\mathrm{CD}^{+} \mathrm{T}$ cell clones secrete the Th1 pattern of cytokines. J Immunol 144: $1744-1752,1990$.

65. Yagi R, Nagai H, Iigo $\mathrm{Y}$, Akimoto $\mathrm{T}$, Arai $\mathrm{T}$ and Kubo $\mathrm{M}$ : Development of atopic dermatitis-like skin lesions in STAT6-deficient NC/Nga mice. J Immunol 168: 2020-2027, 2002.

66. Tan HP, Lebeck LK and Nehlsen-Cannarella SL: Regulatory role of cytokines in IgE-mediated allergy. J Leukoc Biol 52: 115-118, 1992.

67. Barnes PJ and Karin M: Nuclear factor-kappaB: A pivotal transcription factor in chronic inflammatory diseases. N Engl J Med 336: 1066-1071, 1997.

68. Finco TS and Baldwin AS: Mechanistic aspects of NF-kappa $B$ regulation: The emerging role of phosphorylation and proteolysis. Immunity 3: 263-272, 1995.

69. Choi YY, Kim MH, Lee JY, Hong J, Kim SH and Yang WM: Topical application of Kochia scoparia inhibits the development of contact dermatitis in mice. J Ethnopharmacol 154: 380-385, 2014.

70. Arthur JS and Ley SC: Mitogen-activated protein kinases in innate immunity. Nat Rev Immunol 13: 679-692, 2013.

71. Hommes DW, Peppelenbosch MP and van Deventer SJ: Mitogen activated protein (MAP) kinase signal transduction pathways and novel anti-inflammatory targets. Gut 52: 144-151, 2003.

72. Jeon YD, Kee JY, Kim DS, Han YH, Kim SH, Kim SJ, Um JY and Hong SH: Effects of Ixeris dentata water extract and caffeic acid on allergic inflammation in vivo and in vitro. BMC Complement Altern Med 15: 196, 2015.

73. Venuprasad K, Elly C, Gao M, Salek-Ardakani S, Harada Y, Luo JL, Yang C, Croft M, Inoue K, Karin M and Liu YC: Convergence of Itch-induced ubiquitination with MEKK1-JNK signaling in Th2 tolerance and airway inflammation. J Clin Invest 116: 1117-1126, 2006.

74. Campbell JJ, Haraldsen G, Pan J, Rottman J, Qin S, Ponath P, Andrew DP, Warnke R, Ruffing N, Kassam N, et al: The chemokine receptor CCR4 in vascular recognition by cutaneous but not intestinal memory T cells. Nature 400: 776-780, 1999.

75. Hijnen D, De Bruin-Weller M, Oosting B, Lebre C, De Jong E, Bruijnzeel-Koomen C and Knol E: Serum thymus and activation-regulated chemokine (TARC) and cutaneous T cell-attracting chemokine (CTACK) levels in allergic diseases: TARC and CTACK are disease-specific markers for atopic dermatitis. J Allergy Clin Immunol 113: 334-340, 2004.

76. Shimada Y, Takehara K and Sato S: Both Th2 and Th1 chemokines (TARC/CCL17, MDC/CCL22, and Mig/CXCL9) are elevated in sera from patients with atopic dermatitis. J Dermatol Sci 34: 201-208, 2004.
77. Cooper KD: Atopic dermatitis: Recent trends in pathogenesis and therapy. J Invest Dermatol 102: 128-137, 1994.

78. Deshmane SL, Kremlev S, Amini S and Sawaya BE: Monocyte chemoattractant protein-1 (MCP-1): An overview. J Interferon Cytokine Res 29: 313-326, 2009.

79. Homey B, Steinhoff M, Ruzicka T and Leung DY: Cytokines and chemokines orchestrate atopic skin inflammation. J Allergy Clin Immunol 118: 178-189, 2006.

80. Danso MO, van Drongelen V, Mulder A, van Esch J, Scott H, van Smeden J, El Ghalbzouri A and Bouwstra JA: TNF- $\alpha$ and Th2 cytokines induce atopic dermatitis-like features on epidermal differentiation proteins and stratum corneum lipids in human skin equivalents. J Invest Dermatol 134: 1941-1950, 2014

81. Pacheco KA, Tarkowski M, Sterritt C, Negri J, Rosenwasser LJ and Borish L: The influence of diesel exhaust particles on mononuclear phagocytic cell-derived cytokines: IL-10, TGF-beta and IL-1 beta. Clin Exp Immunol 126: 374-383, 2001.

82. Luna JD, Chan CC, Derevjanik NL, Mahlow J, Chiu C, Peng B, Tobe T, Campochiaro PA and Vinores SA: Blood-retinal barrier (BRB) breakdown in experimental autoimmune uveoretinitis: Comparison with vascular endothelial growth factor, tumor necrosis factor alpha, and interleukin-1beta-mediated breakdown. J Neurosci Res 49: 268-280, 1997.

83. Murata T, Watahiki M, Tanaka Y, Miyase T and Yoshizaki F: Hyaluronidase inhibitors from Takuran, Lycopus lucidus. Chem Pharm Bull (Tokyo) 58: 394-397, 2010.

84. Kunz B, Oranje AP, Labreze L, Stalder JF, Ring J and Taieb A: Clinical validation and guidelines for the SCORAD index: Consensus report of the European task force on atopic dermatitis. Dermatology 195: 10-19, 1997.

85. Lee J, Jung E, Koh J, Kim YS and Park D: Effect of rosmarinic acid on atopic dermatitis. J Dermatol 35: 768-771, 2008.

86. Gendrisch F, Esser PR, Schempp CM and Wolfle U: Luteolin as a modulator of skin aging and inflammation. Biofactors 47 : 170-180, 2021.

87. Kang J, Lee S, Kim N, Dhakal H, Choi YA, Kwon TK, Khang D and Kim SH: Hispidulin alleviates 2,4-dinitrochlorobenzene and house dust mite extract-induced atopic dermatitis-like skin inflammation. Biomed Pharmacother 137: 111359, 2021.

This work is licensed under a Creative Commons Attribution-NonCommercial-NoDerivatives 4.0 International (CC BY-NC-ND 4.0) License. 